\title{
A simple and rapid protocol for the genetic transformation of Ensete ventricosum
}

\author{
Jonathan Matheka', Jaindra Nath Tripathi ${ }^{1}$, Ibsa Merga ${ }^{1,2}$, Endale Gebre ${ }^{2}$ and Leena Tripathi ${ }^{1 *}$
}

\begin{abstract}
Enset (Ensete ventricosum), also known as Ethiopian banana, is a food security crop for more than 20 million people in Ethiopia. As conventional breeding of enset is very challenging, genetic engineering is an alternative option to introduce important traits such as enhanced disease resistance and nutritional value. Genetic transformation and subsequent regeneration of transgenic enset has never been reported mainly due to challenges in developing transformation protocols for this tropical species. Agrobacterium-mediated transformation could be a practical tool for the genetic improvement of enset. However, the efficiency of the transformation system depends on several parameters such as plant regeneration, genotype, explant, selection agent and Agrobacterium strains. As a first step towards the development of transgenic enset, a simple and rapid plant regeneration system was developed using multiple buds as explants. Induction and proliferation of multiple buds from shoot tip explants was achieved on Murashige and Skoog (MS) medium supplemented with 5 and $10 \mathrm{mg} / \mathrm{l}$ of 6-benzylaminopurine (BAP), respectively. Shoots were regenerated from multiple buds on MS media containing $2 \mathrm{mg} / \mathrm{I}$ BAP and $0.2 \%$ activated charcoal. Based on the optimized regeneration protocol, an Agrobacterium-mediated transformation method was developed using multiple buds as explants and the binary plasmid pCAMBIA2300-GFP containing the green florescent protein (gfp) reporter gene and neomycin phosphotransferase II (nptll) selection marker gene. Transgenic plantlets were obtained within 4 months at a frequency of about 1.25\%. The transgenic lines were validated by PCR analysis using primers specific to the nptll gene. To obtain uniformly transformed plantlets, chimerism was diluted by subculturing and regenerating the transgenic shoots on a selective medium containing kanamycin $(150 \mathrm{mg} / \mathrm{l})$ for five cycles. The uniformity of the transgenic plants was confirmed by Southern blot hybridization and RT-PCR analyses on different tissues such as leaf, pseudostem and root of same transgenic plant. In the present study, we report a simple Agrobacterium-mediated transformation system for generating transgenic events of enset. To the best of our knowledge, this is the first report on the stable transformation and regeneration of transgenic events of enset. The transformation system established in this study can be used for the generation of transgenic enset with important traits such as disease resistance.
\end{abstract}

Keywords: Ensete ventricosum, Bedadeti, Agrobacterium-mediated transformation, Meristem, Multiple buds, gfp gene

\section{Background}

Ensete ventricosum (commonly known as enset or the Ethiopian banana) is domesticated and cultivated in Ethiopia. It is grown on more than 300,000 ha of land in the central and southwestern parts of the country [1]. About 20 million people depend on it for food [2]. It belongs to the family Musaceae within the order Zingiberales and genus Ensete comprising seven species (Ensete homblei,

\footnotetext{
*Correspondence: L.Tripathi@cgiar.org

${ }^{1}$ International Institute of Tropical Agriculture (IITA), Nairobi, Kenya Full list of author information is available at the end of the article
}

E. perrieri, E. ventricosum, E. livingstonianum, E. glaucum, E. superbum and E. lecongkietii). Three of the species (Ensete ventricosum, E. livingstonianum and $E$. glaucum) are widespread in Africa and Asia. The ensete species are perennial herbaceous flowering plants. They have been exploited for human food, animal fodder, fiber, construction materials, packaging materials, medicine, ornamental value and alleviation of soil erosion [2-4]. E. ventricosum can withstand long periods of drought, heavy rains and flooding. In addition, it can be harvested at any time, even years after the plant reaches maturity, making it an excellent food security crop [4]. 
The major economically important traits for the genetic improvement of enset include high yielding, taste, nutritious, early maturing and resistance to diseases [5]. Bacterial wilt disease caused by Xanthomonas campestris pv. musacearum $(\mathrm{Xcm})$ is one of the most important constraints to enset production. The disease was first observed in Ethiopia on enset in the 1930s but was identified as bacterial wilt in the 1960s [6, 7]. The disease is currently prevalent in all the enset-growing regions in Ethiopia. Xcm also adversely affects banana production in East and Central African countries including Uganda, Tanzania, Kenya, Burundi, Rwanda and DR Congo [8, 9].

The application of conventional approaches to enset breeding is greatly hampered by the long reproductive cycles and poor germination of seeds $[10,11]$. Genetic engineering techniques may be used to accelerate the incorporation of useful traits into enset. During the last decade, different methods of genetic transformation were developed for several crop species. These include approaches for the direct transfer of nucleic acids into cells with and without carrier particles and Agrobacterium tumefaciens-mediated transformation. Agrobacterium-mediated transformation as a tool for genetic improvement has been successfully implemented in Musa species in programs designed to control fusarium wilt [12, 13], bacterial wilt [14] and nematodes [15]. A major drawback to extending these transgenic approaches to other economically important species in the Musacae family (including E. ventricosum) is the lack of efficient regeneration protocols [16]. To date, the main tissue culture technique applied to enset is micropropagation using either intercalary meristems [17] or shoottips [18-21].

Micropropagation has been successfully exploited in the development of transformation procedures for recalcitrant crops [13, 22-24]. Meristem-based approaches have several advantages over those based on callus or somatic embryogenesis including rapidity and low incidences of somaclonal variations [25]. Unlike somatic embryogenesis, which is limited to only a few cultivars, micropropagation is applicable to a wide range of cultivars irrespective of ploidy or genotype. The main challenge with the meristematic explant-based transformation system is the production of chimeric transgenic plants resulting from gene transfer to a small number of the multiple cells involved in the development of shoot meristem [22, 23]. However, homogeneously transformed plants can be obtained through the manipulation of the tissue culture and selection process [26].

Gene transfer using Agrobacterium and regeneration of transgenic plants are influenced by different factors. The key parameters influencing the ability to develop transgenic plants include the type of explant, Agrobacterium strain, binary vector, selection agent and compositions of the inoculation and co-culture medium. In addition, treatments such as micro-wounding of explants prior to transformation [27] and vacuum infiltration of explants before co-cultivation with Agrobacterium [24] enhanced the transformation of different plant species. Currently, there are no reports of stable genetic transformation and regeneration of transgenic events of enset. Birmeta [19] provided the evidence showing that enset tissues are sensitive to Agrobacterium infection, however, regeneration of transgenic plants from the transformed tissues and stable integration of transgene were not demonstrated. In the report, zygotic embryos, leaf and root tissues of two clones of enset (Feresae and Erba) were transiently transformed with the gusA reporter gene.

In the present study, we report the development of a simple and rapid protocol for the stable transformation and regeneration of transgenic events of enset using multiple meristematic buds. To significantly improve the transformation efficiency, we optimized the effect of micro-wounding through sonication, different Agrobacterium strains, co-cultivation media and resting duration. The effect of these parameters was studied individually and then we came up with a comprehensive protocol where all these modifications were combined to attain maximum transformation efficiency. In addition, we have developed a protocol for the elimination of chimeras in transgenic plantlets. Using this protocol, we obtained uniformly transformed plantlets, thus overcoming the main obstacle in the genetic manipulation of enset.

\section{Materials and methods \\ Plant materials}

Ensete ventricosum cv. Bedadeti used in this study was acquired from the Ethiopian Institute of Agricultural Research (EIAR), Ethiopia, as in vitro plantlets. The plantlets were multiplied by monthly subculturing on shoot elongation medium (SEM4, Table 1) under controlled temperature $\left(25 \pm 2{ }^{\circ} \mathrm{C}\right)$ and light $(16: 8$-h photoperiod and $80 \mathrm{mmol} / \mathrm{m}^{2} / \mathrm{s}$ irradiance) conditions in a growth room.

\section{Optimization of enset regeneration using multiple buds as explants}

The effect of different concentrations $(2.5,5,10,15$, $22 \mathrm{mg} / \mathrm{l}$ ) of 6-Benzylaminopurine (BAP) on the induction of multiple buds was evaluated. Shoot tips having a small section of corm tissue with some leaf primordia (Fig. 1a) were isolated from in vitro plantlets by removing the roots and pseudostem. The shoot tip was split longitudinally into two (Fig. 1b) and cultured on bud induction medium (BIM) containing different concentrations of BAP (Table 1). Explants were kept in 
Table 1 Composition of various media used in tissue culture and transformation of enset

\begin{tabular}{|c|c|}
\hline Medium name & Components \\
\hline Bud induction medium 1 (BIM1) & MS ${ }^{a}$ medium supplemented with $10 \mathrm{mg} / \mathrm{l}$ ascorbic acid, $30 \mathrm{~g} / \mathrm{l}$ sucrose and $2.5 \mathrm{mg} / \mathrm{l} \mathrm{BAP,}$ pH5.8 and $3 \mathrm{~g} / \mathrm{l}$ gelrite \\
\hline Bud induction medium 2 (BIM2) & MS medium supplemented with $10 \mathrm{mg} / \mathrm{l}$ ascorbic acid, $30 \mathrm{~g} / \mathrm{l}$ sucrose and 5 mg/l BAP, pH5.8 and 3 g/l gelrite \\
\hline Bud induction medium 3 (BIM3) & MS medium supplemented with 10 mg/l ascorbic acid, $30 \mathrm{~g} / \mathrm{l}$ sucrose and 10 mg/l BAP, pH5.8 and 3 g/l gelrite \\
\hline Bud induction medium 4 (BIM4) & MS medium supplemented with 10 mg/l ascorbic acid, $30 \mathrm{~g} / \mathrm{l}$ sucrose and 15 mg/l BAP, pH5.8 and 3 g/l gelrite \\
\hline Bud Induction Medium 5 (BIM5) & MS medium supplemented with 10 mg/l ascorbic acid, $30 \mathrm{~g} / \mathrm{l}$ sucrose and 22 mg/l BAP, pH5.8 and 3 g/l gelrite \\
\hline Bud multiplication medium 1 (BMM1) & $\begin{array}{l}\text { MS medium supplemented with } 10 \mathrm{mg} / \mathrm{l} \text { ascorbic acid, } 30 \mathrm{~g} / \mathrm{l} \text { sucrose, } 0.175 \mathrm{mg} / \mathrm{l} \mathrm{IAA}, 2.5 \mathrm{mg} / \mathrm{l} \mathrm{BAP,} \text { pH5.8 and } \\
3 \mathrm{~g} / \mathrm{l} \text { gelrite }\end{array}$ \\
\hline Bud multiplication medium 2 (BMM2) & $\begin{array}{l}\text { MS medium supplemented with } 10 \mathrm{mg} / \mathrm{l} \text { ascorbic acid, } 30 \mathrm{~g} / \mathrm{I} \text { sucrose, } 0.175 \mathrm{mg} / \mathrm{IAA}, 5 \mathrm{mg} / \mathrm{I} \text { BAP, pH5.8 and } \\
3 \mathrm{~g} / \mathrm{l} \text { gelrite }\end{array}$ \\
\hline Bud multiplication medium 3 (BMM3) & $\begin{array}{l}\text { MS medium supplemented with } 10 \mathrm{mg} / \mathrm{l} \text { ascorbic acid, } 30 \mathrm{~g} / \mathrm{l} \text { sucrose, } 0.175 \mathrm{mg} / \mathrm{I} \text { IAA, } 10 \mathrm{mg} / \mathrm{l} \mathrm{BAP,} \text { pH5.8 and } \\
3 \mathrm{~g} / \mathrm{l} \text { gelrite }\end{array}$ \\
\hline Bud multiplication medium 4 (BMM4) & $\begin{array}{l}\text { MS medium supplemented with } 10 \text { mg/l ascorbic acid, } 30 \mathrm{~g} / \mathrm{I} \text { sucrose, } 0.175 \mathrm{mg} / \mathrm{I} \text { IAA, } 15 \text { mg/l BAP, pH5.8 and } \\
3 \mathrm{~g} / \mathrm{l} \text { gelrite }\end{array}$ \\
\hline Bud multiplication medium 5 (BMM5) & $\begin{array}{l}\text { MS medium supplemented with } 10 \text { mg/l ascorbic acid, } 30 \mathrm{~g} / \mathrm{l} \text { sucrose, } 0.175 \text { mg/l IAA, } 22 \text { mg/l BAP, pH5.8 and } \\
3 \mathrm{~g} / \mathrm{l} \text { gelrite }\end{array}$ \\
\hline Shoot elongation medium 1 (SEM1) & $\begin{array}{l}\text { MS medium supplemented with } 10 \mathrm{mg} / \mathrm{l} \text { ascorbic acid, } 30 \mathrm{~g} / \mathrm{l} \text { sucrose, } 0.2 \% \text { AC, } 0.1 \mathrm{mg} / \mathrm{l} \text { BAP, pH5.8 and } 3 \mathrm{~g} / \mathrm{l} \\
\text { gelrite }\end{array}$ \\
\hline Shoot elongation medium 2 (SEM2) & $\begin{array}{l}\text { MS medium supplemented with } 10 \mathrm{mg} / \mathrm{l} \text { ascorbic acid, } 30 \mathrm{~g} / \mathrm{l} \text { sucrose, } 0.2 \% \text { AC, } 0.5 \text { mg/l BAP, pH5.8 and } 3 \mathrm{~g} / \mathrm{l} \\
\text { gelrite }\end{array}$ \\
\hline Shoot elongation medium 3 (SEM3) & $\begin{array}{l}\text { MS medium supplemented with } 10 \mathrm{mg} / \mathrm{l} \text { ascorbic acid, } 30 \mathrm{~g} / \mathrm{l} \text { sucrose, } 0.2 \% \text { AC, } 1.0 \mathrm{mg} / \mathrm{l} \text { BAP, pH5.8 and } 3 \mathrm{~g} / \mathrm{l} \\
\text { gelrite }\end{array}$ \\
\hline Shoot elongation medium 4 (SEM4) & $\begin{array}{l}\text { MS medium supplemented with } 10 \text { mg/l ascorbic acid, } 30 \mathrm{~g} / \mathrm{l} \text { sucrose, 0.2\% AC, } 2.0 \text { mg/l BAP, pH5.8 and } 3 \mathrm{~g} / \mathrm{l} \\
\text { gelrite }\end{array}$ \\
\hline Shoot elongation medium 5 (SEM5) & 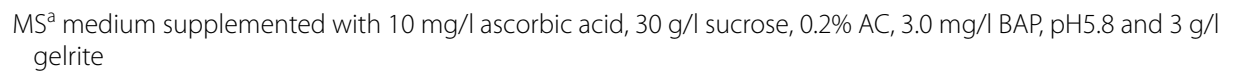 \\
\hline Root induction medium 1 (RIM1) & MS medium supplemented with 10 mg/l ascorbic acid, $30 \mathrm{~g} / \mathrm{l}$ sucrose, 1 mg/I IBA, pH5.8 and 3 g/l gelrite \\
\hline Root induction medium 2 (RIM2) & $\begin{array}{l}\text { MS medium supplemented with } 10 \text { mg/l ascorbic acid, } 30 \mathrm{~g} / \mathrm{l} \text { sucrose, } 1 \mathrm{mg} / \mathrm{l} \text { IBA, } 0.1 \mathrm{mg} / \mathrm{l} \text { BAP, pH5.8 and } 3 \mathrm{~g} / \mathrm{l} \\
\text { gelrite }\end{array}$ \\
\hline Root induction medium 3 (RIM3) & $\begin{array}{l}\text { MS medium supplemented with } 10 \text { mg/l ascorbic acid, } 30 \mathrm{~g} / \mathrm{l} \text { sucrose, } 1 \mathrm{~m} \text { g/l IBA, } 0.25 \text { mg/l BAP, pH5.8 and } \\
3 \mathrm{~g} / \text { l gelrite }\end{array}$ \\
\hline Root induction medium 4 (RIM4) & $\begin{array}{l}\text { MS medium supplemented with } 10 \mathrm{mg} / \mathrm{l} \text { ascorbic acid, } 30 \mathrm{~g} / \mathrm{l} \text { sucrose, } 1 \mathrm{~m} \text { g/l IBA, } 0.5 \mathrm{mg} / \mathrm{l} \mathrm{BAP,} \mathrm{pH} 5.8 \text { and } 3 \mathrm{~g} / \mathrm{I} \\
\text { gelrite }\end{array}$ \\
\hline Cocultivation medium A (CCA) & $\begin{array}{l}\text { MS medium supplemented with } 30 \mathrm{~g} / \mathrm{l} \text { sucrose, } 10 \mathrm{mg} / \mathrm{l} \text { Ascorbic Acid, } 1 \mathrm{mg} / \mathrm{l} \mathrm{BAP,} \mathrm{pH} 5.8 \text { and } 0.3 \% \text { gelrite. } \\
\text { Acetosyringone }(200 \mu \mathrm{M}) \text { was added post-autoclaving }\end{array}$ \\
\hline Cocultivation medium B (CCB) & $\begin{array}{l}\text { MS medium supplemented with } 30 \mathrm{~g} / \mathrm{l} \text { sucrose, } 10 \mathrm{mg} / \mathrm{l} \text { Ascorbic Acid, } 1 \mathrm{mg} / \mathrm{l} \mathrm{BAP,} 10 \mathrm{~g} / \mathrm{l} \text { glucose, pH } 5.8 \text { and } \\
0.3 \% \text { gelrite. Acetosyringone }(200 \mu \mathrm{M}) \text { was added post-autoclaving }\end{array}$ \\
\hline Regeneration medium (RM) & MS medium supplemented with 10 mg/l ascorbic acid, 1 mg/l BAP, 30 g/l sucrose, pH5.8 and 3 g/l gelrite \\
\hline Infection medium (IM) & $\begin{array}{l}\text { MS salts (M0222) supplemented with } 10 \text { mg/l ascorbic acid, } 1 \text { mg/l BAP, } 30 \text { g/l sucrose, pH 5.8, and } 3 \text { g/l gelrite } \\
\text { and } 200 \mu \mathrm{M} \text { acetosyringone added after autoclaving }\end{array}$ \\
\hline Resting medium (RestM) & $\begin{array}{l}\text { MS salts (M0222) supplemented with } 10 \text { mg/l ascorbic acid, } 1 \text { mg/l BAP, } 30 \text { g/l sucrose, pH 5.8, and } 3 \text { g/l gelrite } \\
\text { and } 300 \text { mg/l cefotaxim added after autoclaving }\end{array}$ \\
\hline Selective regeneration medium (SRM) & $\begin{array}{l}\text { MS salts (M0222) supplemented with } 10 \text { mg/l ascorbic acid, } 1 \text { mg/l BAP, } 30 \mathrm{~g} / \mathrm{l} \text { sucrose, pH 5.8, and } 3 \mathrm{~g} / \mathrm{l} \text { gelrite } \\
\text { and } 300 \mathrm{mg} / \mathrm{l} \text { cefotaxim and } 150 \mathrm{mg} / \mathrm{l} \mathrm{kanamycin} \mathrm{added} \mathrm{after} \mathrm{autoclaving}\end{array}$ \\
\hline
\end{tabular}

$B A P$ 6-benzylaminopurine, IAA indole acetic acid, 2,4-D 2,4-dichlorophenoxyacetic acid, $A c$ activated charcoal

a Murashige and Skoog [45]

a growth room at $25^{\circ} \mathrm{C}$ in the dark for 6 weeks. The explants were transferred to a fresh medium every 3 weeks and observed for bud induction (Fig. 1c, d). The weight of each explant was recorded before culture and after 6 weeks of culture. There were 6 replicates for each treatment, and the experiment was repeated twice.

The effect of different concentrations $(2.5,5,10,15$, $22 \mathrm{mg} / \mathrm{l}$ ) of BAP was evaluated for the proliferation of induced multiple buds. A thin dorm-shaped slice $(2 \mathrm{~mm}$ thick, 3-4 $\mathrm{mm}$ long and 2-3 mm wide) (Fig. 1e) was excised from the buds induced on the shoot tips cultured on BIM2 containing $5 \mathrm{mg} / \mathrm{l} \mathrm{BAP}$. The bud explants were cultured on bud multiplication medium (BMM) containing various concentration $(2.5,5,10,15,22 \mathrm{mg} / \mathrm{l})$ of BAP and $0.175 \mathrm{mg} / \mathrm{l} \mathrm{IAA} \mathrm{(Table} \mathrm{1).} \mathrm{Explants} \mathrm{were} \mathrm{kept}$ in a growth room at $25{ }^{\circ} \mathrm{C}$ in the dark for 8 weeks. The 

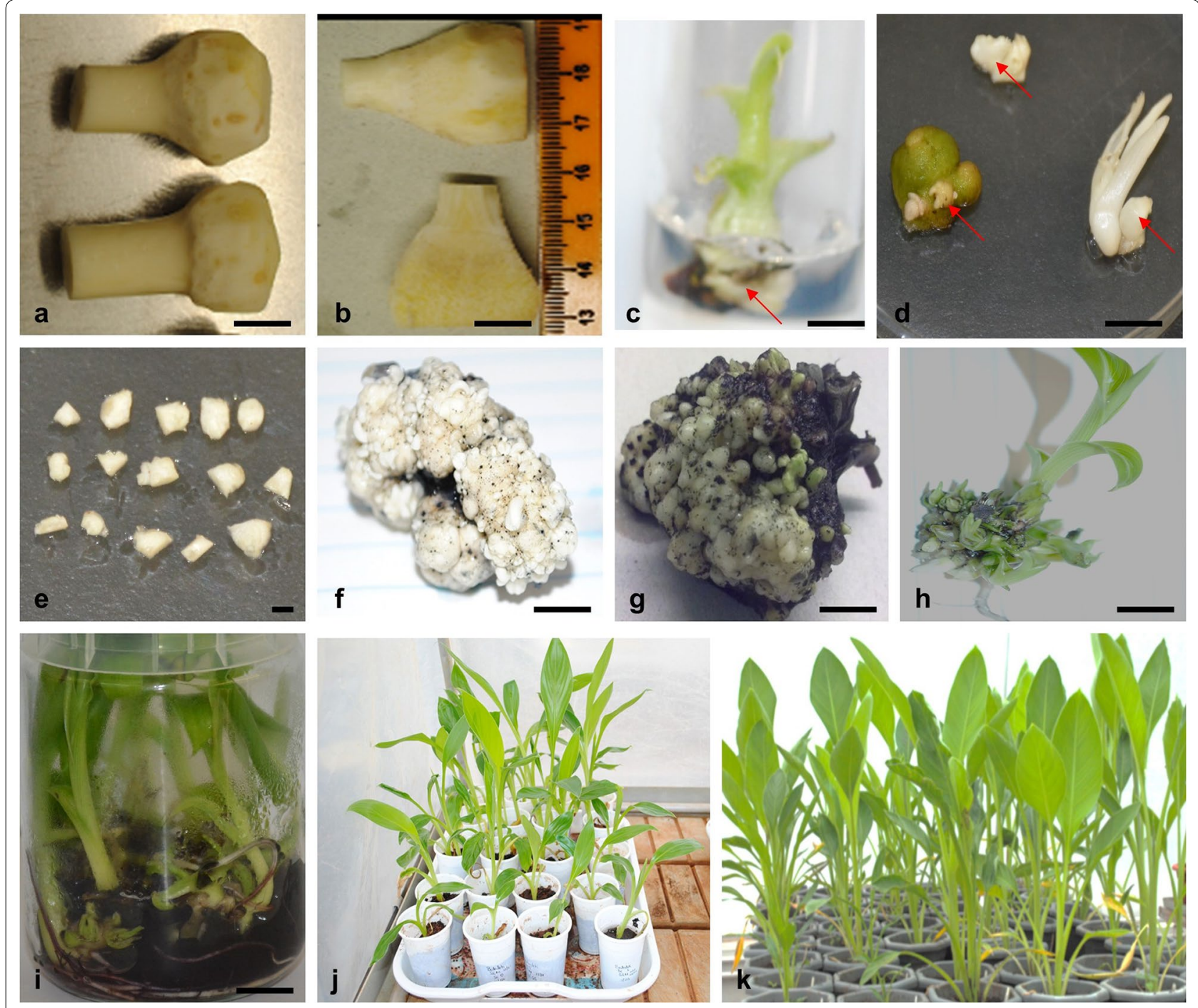

Fig. 1 Regeneration of enset through multiple buds. a Shoot tip, b half split shoot tips used as explants for bud induction, $\mathbf{c}$ bud induced (indicated by arrow) from shoot tip explants cultured on the bud induction medium (BIM), $\mathbf{d}$ explants showing induced buds (indicated by arrow), e thin slices of excised buds induced on the shoot tips cultured on BIM, $\mathbf{f}$ multiple buds induced on explant cultured on the bud multiple medium (BMM), $\mathbf{g}$ induction of sprouting of buds on the shoot elongation medium (SEM), $\mathbf{h}$ shoots regenerated from multiple buds cultured on SEM having $2.0 \mathrm{mg} / \mathrm{l}$ BAP and $0.2 \%$ activated charcoal, $\mathbf{i}$ complete plantlets on SEM, $\mathbf{j}$ enset plantlets undergoing weaning in a humidity chamber in the glasshouse, $\mathbf{k}$ potted enset plants growing in the glasshouse. Scale bar $=1 \mathrm{~cm}$ for $\mathbf{a}-\mathbf{d}, \mathbf{f}-\mathbf{i}$ and $2 \mathrm{~mm}$ for $\mathbf{e}$

cultures were subcultured to fresh medium every 4 weeks for bud proliferation (Fig. 1f, g). The weight of each proliferating bud clump was recorded after 8 weeks of culture. There were 4 replicates for each treatment, and the experiment was repeated twice.

The effect of different concentrations $(0.1,0.5,1.0$, $2.0,3.0 \mathrm{mg} / \mathrm{l})$ of BAP on shoot regeneration from multiple buds was evaluated. Dorm-shaped explants $(2 \mathrm{~mm}$ thick, 3-4 $\mathrm{mm}$ long and $2-3 \mathrm{~mm}$ wide) having multiple buds were excised from 90-day-old cultures proliferating on BMM3 and transferred to shoot induction and elongation media (SEM) containing different concentrations of BAP (Table 1). The cultures were incubated at a photoperiod of $16 \mathrm{~h}$ light $/ 8 \mathrm{~h}$ dark at $25^{\circ} \mathrm{C}$ for 8 weeks with subculturing to fresh medium every 4 weeks. The percentage of explants inducing shoots, number of shoots per explant and shoot length were recorded after 8 weeks of culture. Three explants were used for treatment in each medium and the experiment was repeated three times.

To evaluate the rooting response of shoots, media supplemented with $1 \mathrm{mg} / \mathrm{l} \mathrm{IBA}$ and different concentrations 
$(0.1,0.25,0.5,1.0,2.0 \mathrm{mg} / \mathrm{l})$ of BAP were tested. Shoots (1.0-1.5 cm long) were excised from regenerating bud clumps (Fig. 1h) and cultured on root induction media (RIM) containing IBA and different concentrations of BAP (Table 1). Three explants were used for each media treatment and replicated three times. Cultures were incubated at $25 \pm 2{ }^{\circ} \mathrm{C}$ with a $16 / 8 \mathrm{~h}$ photoperiod. Data on shoot length, number of roots per shoot and length of roots per explant was recorded after 7 days.

Complete plantlets were maintained on SEM with $2 \mathrm{mg} / \mathrm{l} \mathrm{BAP}$ and $0.2 \%$ activated charcoal (Fig. 1i). Wellrooted plantlets were removed from the culture media and gently washed with water to remove any remaining medium from the roots. The clean plantlets were then transferred to plastic disposable cups containing sterile soil ( $80 \%$ loam soil and $20 \%$ manure) (Fig. 1j). Plantlets were placed in a high humidity chamber (made of transparent polythene sheets) in the glasshouse and watered with tap water. Plantlets were removed from the chamber after 2 weeks and transferred to pots (10 l) containing sterile soil (Fig. 1k). Plants were maintained under the humid chamber in the glasshouse. Data on survival of plantlets in the pots and number of plants showing somaclonal variations was recorded 4 weeks after potting.

\section{Optimization of Agrobacterium-mediated transformation of enset using multiple buds as explants Kill curve analysis of multiple buds on medium containing kanamycin}

The sensitivity of multiple buds to kanamycin was tested by culturing the explants on RM (Table 1) supplemented with various concentrations of kanamycin $(0,50,100$, $150,200 \mathrm{mg} / \mathrm{l})$. The cultures were incubated at $25 \pm 2{ }^{\circ} \mathrm{C}$ with a $16 / 8 \mathrm{~h}$ photoperiod. The tissues were assessed for shoot regeneration up to 60 days after culture. This assay was performed to establish the minimum inhibitory concentration for the selection of transformed tissues. A positive control in which explants were cultured without a selection agent was included.

\section{Bacterial strains and plasmid constructs}

Agrobacterium tumefaciens strains EHA105 or LBA4404 harboring the binary vector pCAMBIA2300-GFP (Additional file 1: Fig. S1) was used in this study. The vector contains a green fluorescent protein ( $g f p$ ) reporter gene under the control of a constitutive CaMV35S promoter. The plasmid vector also contains the neomycin phosphotransferase II (nptII) gene under the regulation of a CaMV35S promoter for plant selection. EHA105 is a super virulent strain of the agropine type having the pEHA105 helper plasmid [28], while LBA4404 is an octopine type strain having the pAL4404 helper plasmid [29]. A. tumefaciens LBA4404:pCAMBIA2300-GFP or EHA105:pCAMBIA2300-GFP cells were streaked on solid Luria-Bertani (LB) medium (1\% tryptone, $0.5 \%$ yeast extract, and $1 \% \mathrm{NaC} 1, \mathrm{pH} 7.0)$ containing $50 \mathrm{mg} / \mathrm{l}$ kanamycin and $25 \mathrm{mg} / \mathrm{l}$ rifampicin. The cultures were incubated in the dark at $28{ }^{\circ} \mathrm{C}$ for $48 \mathrm{~h}$. One colony was selected and inoculated in liquid LB medium. The cultures were kept in the dark at $28^{\circ} \mathrm{C}$ with shaking (New Brunswick Scientific incubator shaker, Model Innova 44, Eppendorf AG, Germany) at 200 revolutions per minute (rpm) for $48 \mathrm{~h}$. The Agrobacterium culture was used as a seed culture to inoculate $100 \mathrm{ml}$ of LB medium and cultured for $12 \mathrm{~h}$ at $28{ }^{\circ} \mathrm{C}$. The culture was centrifuged for $10 \mathrm{~min}$ at $4000 \mathrm{rpm}$ and resuspended in $25 \mathrm{ml}$ of infection media (IM) (Table 1). The culture was incubated at $28^{\circ} \mathrm{C}$ with shaking at $60 \mathrm{rpm}$ for $1 \mathrm{~h} . \mathrm{OD}_{600}$ of the culture was adjusted to 0.5 before co-cultivation with explants.

\section{Expression of gfp reporter gene in transgenic tissues}

Tissues from transgenic and control non-transgenic lines were examined under a fluorescence stereomicroscope (SMZ 1500, Nikon Corporation, Tokyo, Japan) at an excitation B filter for wavelength ranges between 460 and $490 \mathrm{~nm}$. Chlorophyll was partially removed from leaf tissues obtained from putative transgenic and wild type plants before examination. This was achieved by treating the leaf tissues with methanol for 20 min followed by soaking in distilled water. Photographs were taken using a digital camera attached to the stereomicroscope.

\section{Effect of co-cultivation media on transformation efficiency}

The effect of co-culture media on enset genetic transformation was evaluated. Multiple buds (2 mm thick, 3-4 $\mathrm{mm}$ long and 2-3 mm wide) isolated from 3-month old proliferating multiple bud cultures were collected into $50 \mathrm{ml}$ tubes containing about $30 \mathrm{ml}$ of infection medium (Table 1). The multiple buds were infected with EHA105:pCAMBIA2300-GFP for $30 \mathrm{~min}$ and vacuum infiltrated for $5 \mathrm{~min}$. The Agro-infected tissues were cocultivated for 3 days on either co-cultivation medium A or B (CCA or CCB, Table 1). For each medium treatment, 30 explants were used. UV illumination from a fluorescence stereomicroscope was used to detect $g f p$ fluorescence on the explants after 3 days. Data on number of explants with $g f p$ fluorescence were recorded.

\section{Effect of sonication on transformation efficiency}

To determine the effect of sonication on the genetic transformation of enset, explants isolated from 3-month old proliferating multiple buds were sonicated (Decon FS400b, 400 W, 35-45 kHz, Decon LTD., UK) for different durations $[0,5,50$, or $100 \mathrm{~s}(\mathrm{sec})]$. Sonicated explants were infected with EHA105:pCAMBIA2300-GFP and 
cultured on CCA for 3 days in the dark at $25{ }^{\circ} \mathrm{C}$. The expression of $g f p$ gene was determined as green fluorescence for each infected explant. Each experiment comprised 30 explants with three replicates each. Data on number of explants with $g f p$ fluorescence were recorded 3 days after co-cultivation.

\section{Effect of Agrobacterium strain on transformation efficiency}

To establish the effect of Agrobacterium strains on enset transformation, explants from 3-month old multiple buds were infected with EHA105:pCAMBIA2300-GFP or LBA4404:pCAMBIA2300-GFP. The explants were cultured in CCA and kept in the dark at $22^{\circ} \mathrm{C}$. Data on the number of explants with $g f p$ fluorescence were recorded 3 days after co-cultivation. Each experiment comprised 30 explants with three replicates.

\section{Effect of resting duration on shoot bud regeneration from Agro-infected explants}

To evaluate the effect of resting on enset transformation, explants from 3-month old proliferating multiple buds were infected with EHA105:pCAMBIA2300-GFP and cultured in CCA. Explants were kept in the dark at $22{ }^{\circ} \mathrm{C}$ for 3 days. Explants were washed by transferring 50 explants to $50 \mathrm{ml}$ sterile plastic tubes with liquid $\mathrm{CM}$ media having $500 \mathrm{mg} / \mathrm{l}$ cefotaxime. Explants were incubated at room temperature with shaking $(70 \mathrm{rpm})$ on an orbital shaker. Washed explants were blotted dry and cultured on resting media (RestM) for different durations ( 0 or 30 days) before transferring to selective regeneration media (SRM) containing $150 \mathrm{mg} / \mathrm{l} \mathrm{kanamycin.} \mathrm{The} \mathrm{num-}$ ber of kanamycin-resistant explants with sprouting buds was recorded 30 days after transfer of explants to SRM.

\section{Stable transformation of enset using multiple buds as explants}

A total of 400 explants excised from 90-day old cultures of multiple buds were kept in eight $50 \mathrm{ml}$ tubes each containing $30 \mathrm{ml}$ of infection media (Table 1). The explants were sonicated for $5 \mathrm{~s}$ and then co-cultivated with LBA4404:pCAMBIA2300-GFP suspension $(\mathrm{OD} 600=0.5)$ at room temperature $\left(25^{\circ} \mathrm{C}\right)$ with shaking at $30 \mathrm{rpm}$ for $30 \mathrm{~min}$. The bacterial cell suspension was prepared as previously described. An experiment in which sonicated explants were not infected with bacteria was included as the control. Tissues were blotted dry, cultured on CCA media (Table 1) and incubated at $22{ }^{\circ} \mathrm{C}$ for 3 days. Explants were placed on regeneration medium (RM) without selection (Table 1) for 7 days at $26{ }^{\circ} \mathrm{C}$ in the dark for resting. After that, explants were transferred to SRM containing $150 \mathrm{mg} / \mathrm{l}$ kanamycin and $300 \mathrm{mg} / \mathrm{l}$ cefotaxime for 21 days in the dark. All tissues were subcultured twice in the fresh SRM. The control non-transformed explants were also cultured on selective medium. The putatively transformed shoots were regenerated on SRM. Meristem, leaf and root tissues were excised from the putatively transformed shoots regenerated on SRM to confirm the stable expression of $g f p$ gene. To obtain uniformly transformed plants, all putative transgenic shoots were treated to a further round of selection on $150 \mathrm{mg} / \mathrm{l}$ kanamycin. To achieve this, shoot tip explants $(1 \mathrm{~cm}$ long $\times 0.5 \mathrm{~cm}$ wide $)$ from putative transgenic plantlets were cultured on RIM3 with $150 \mathrm{mg} / \mathrm{l}$ kanamycin (named as CDM1 media) for shoot elongation. After 7 days of culture, explants were transferred to RIM1 with $150 \mathrm{mg} / \mathrm{l} \mathrm{kanamycin}$ (named as CDM2 media) for 2 weeks for root development. This process was repeated five times. Plantlets having a robust rooting system and fully developed green leaves were deemed non-chimeric, uniformly transformed and further confirmed through molecular analyses. Confirmed transgenic plantlets were maintained on SEM4 medium.

\section{Molecular analyses Polymerase chain reaction (PCR) analysis}

PCR analysis was performed to confirm the presence of transgene in the GFP-fluorescing transgenic plants. Genomic DNA (gDNA) was isolated from young leaf, pseudostem or roots of putative transgenic and control non-transgenic plants using the DNeasy kit (Qiagen, $\mathrm{GmbH}$, Germany). The gDNA was subjected to PCR analysis to detect the presence of $n p t I I$ gene with a predicted fragment size of $780 \mathrm{bp}$. Plasmid pCAMBIA2300GFP and gDNA from a non-transgenic plant were used as a positive and negative control, respectively. Specific primers for $n p t \mathrm{II}$ gene used were: forward $5^{\prime}$ GATGGA TTGCACGCAGGTTCTC $3^{\prime}$ and reverse $5^{\prime}$ CAGAAG AACTCGTCAAGAAGGC $3^{\prime}$. PCR was carried out in a $25 \mu \mathrm{l}$ reaction volume containing (1X) HotStart master mix (Qiagen) and $100 \mathrm{ng}$ of sample DNA. The reaction mixtures were subjected to the following amplification conditions: initial denaturation at $95{ }^{\circ} \mathrm{C}$ for $15 \mathrm{~min}, 25$ cycles of denaturation at $94{ }^{\circ} \mathrm{C}$ for $30 \mathrm{~s}$, annealing at $68^{\circ} \mathrm{C}$ for $30 \mathrm{~s}$, extension at $72{ }^{\circ} \mathrm{C}$ for $1 \mathrm{~min}$ and a final extension at $72{ }^{\circ} \mathrm{C}$ for $2 \mathrm{~min}$. The amplified fragments were separated by electrophoresis on $1 \%(\mathrm{w} / \mathrm{v})$ agarose stained with gel red. In total, 12 putative transgenic events were tested by PCR to confirm the presence of $n p t I I$ gene.

\section{Southern blot analysis}

For additional confirmation of transgene integration, Southern blot analysis was performed with two PCR positive events using the method described in [14]. Briefly, gDNA was extracted from leaf tissues using the CTAB extraction method. Twenty micrograms of gDNA were digested overnight at $37^{\circ} \mathrm{C}$ with HindIII, which cuts only 
once within the T-DNA region of the plasmid vectors used in transformation. Digested DNA was separated by electrophoresis in $0.8 \%$ agarose gel. The DNA was blotted onto a positively charged nylon membrane (Roche Diagnostics, Lewes, East Sussex, UK) by upward capillary in a $20 \times$ SSC buffer. A digoxigenin (DIG)-dUTP labelled $n p t I I$ probe was hybridized to the blotted DNA. Hybridizing bands corresponding to the $n p t I I$ gene were visualized by exposure to an X-ray film (Roche Diagnostics, Lewes, East Sussex, UK) for $30 \mathrm{~min}$.

\section{Reverse transcription polymerase chain reaction (RT-PCR) analysis}

RT-PCR was performed to confirm transgene expression on uniformly transformed plants. Total RNA was extracted from leaf, pseudostem and roots of two transgenic events using the RNeasy plant mini kit (Qiagen, $\mathrm{GmbH}$, Germany). DNase I treatment was performed for all samples. For each sample, $1 \mu \mathrm{g}$ RNA was used for cDNA preparation using the ProtoScript First strand cDNA synthesis kit (New England Biolabs Inc., Ma, USA). Two microliters of cDNA were used in a PCR reaction to detect $n p t I$ gene transcripts using gene-specific primers. For each sample cDNA, primers for the endogenous small subunit rRNA gene were used for internal control amplification.

\section{Data collection and statistical analysis}

All experiments were conducted as completely randomized designs. Data on frequency of GFP positive explants, bud induction frequency, number of shoots per explant, shoot height, root length and number of roots were collected. Data on frequency of GFP positive explants and bud induction frequency were square root transformed before analysis. Data were subjected to analysis of variance and treatment means were compared using Tukey's test $(p=0.05)$ and $\mathrm{R}$ statistical programming language.

\section{Results and discussion}

This study was conducted to establish an efficient Agrobacterium-mediated transformation system for enset cultivar Bedadeti. This system could then be applied to other farmer-preferred enset cultivars. We tried to transform enset using multiple meristematic buds as explants since this approach is potentially rapid and applicable to different cultivars. We then optimized the regeneration of Bedadeti using multiple buds as explants to make the procedure more efficient. The optimized regeneration protocol was adapted to transformation.

\section{Optimization of enset regeneration using multiple buds} Induction and proliferation of multiple buds

Media containing different concentrations of BAP were tested for efficiency of bud induction from shoot tip explants. Four weeks after culture, buds as smooth white swellings were induced on the explants cultured on all the media tested (Fig. 1c, d). The response of bud induction from shoot tip explants slightly varied according to the amount of BAP used in the proliferation media. However, no significant differences $(p=0.7570)$ were observed among the different media tested for bud induction. The BIM1 medium promoted bud induction from shoot tip explants after 30 days of culture. However, the buds sprouted quickly upon sub-culturing on the same medium, making the medium unsuitable for sustained bud proliferation. Multiple buds were most efficiently induced on shoot tips in the presence of media with $5 \mathrm{mg} / \mathrm{l} \mathrm{BAP}$ (BIM2), which resulted in a $1.2 \mathrm{~g}$ weight gain per explant after 6 weeks of culture (Fig. 2a). Higher levels of BAP (10 or $22 \mathrm{mg} / \mathrm{l}$ ) induced buds that grew slowly and were highly blackened. Based on these observations, explants were cultured on media supplemented with $5 \mathrm{mg} / \mathrm{l} \mathrm{BAP}$ (designated as bud induction medium [BIM] for further experiments) for optimal bud induction. Previous studies reported bud induction at lower BAP concentrations $(1.5-4.5 \mathrm{mg} / \mathrm{l})[18,19]$ or in combination with an auxin such as IAA or ABA $[19,20]$.

To obtain the best response for bud proliferation, several media with different concentrations of BAP and $0.175 \mathrm{mg} / \mathrm{l}$ IAA were compared. The growth response of explants cultured on the different media is shown in Fig. 2b. The best growth response was obtained with media treatment BMM1 (with $2.5 \mathrm{mg} / \mathrm{l} \mathrm{BAP}$ ) and BMM3 (with $10 \mathrm{mg} / \mathrm{l} \mathrm{BAP}$ ). However, the optimal media treatment was BMM3, which resulted in bud proliferation (Fig. 1f) with relatively lower regeneration than treatment BMM1 which resulted in sprouting of multiple buds 14 days after culture of explants. Cultures on BMM4 (15 mg/l BAP) and BMM5 (22 mg/l BAP) were either unresponsive or grew very slowly due to intense blackening. Therefore, the medium with $10 \mathrm{mg} / \mathrm{l} \mathrm{BAP}$ (designated as bud multiplication medium [BMM]) was used for bud multiplication in subsequent experiments.

For enset, media with a high cytokinin/auxin ratio is commonly used for bud multiplication. A 2.5-20-fold higher cytokinin than auxin concentration was essential for multiplication of buds for some enset cultivars [19, $21,30,31]$. However, in this study, bud multiplication was achieved for enset cultivar Bedadeti with a 50-fold higher BAP than IAA concentration. Growth conditions for bud multiplication include temperatures of $23-27{ }^{\circ} \mathrm{C}$ and a $16-\mathrm{h}$ photoperiod at $3000 \mathrm{~lx}[20,30,31]$. However, 
a

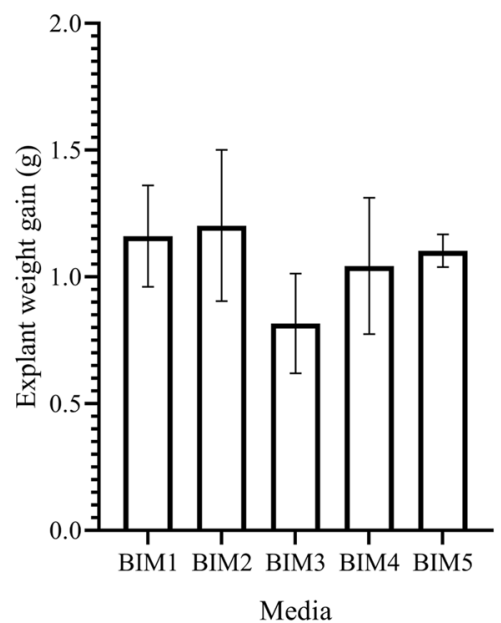

b

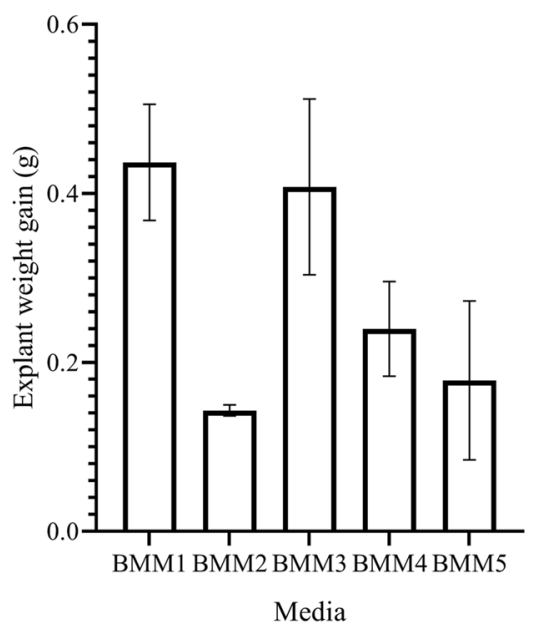

C

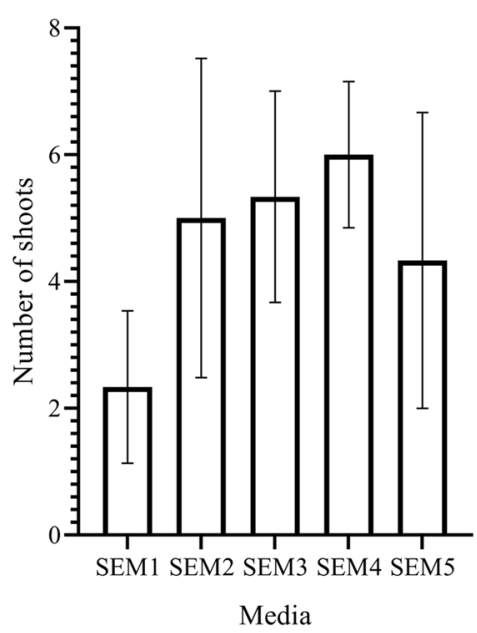

Fig. 2 Effect of different media on bud induction, bud proliferation and shoot regeneration from multiple buds of enset. a Effect of different media on weight gain of shoot tip explants cultured on bud induction medium (BIM), $\mathbf{b}$ effect of different media on weight gain of explants cultured on bud multiplication medium (BMM), c effect of different media on the number of shoots regenerated from cluster of multiple buds cultured on shoot elongation medium (SEM). The bars represent mean and standard error for values of weight gain or number of shoots

this study reports that buds are best multiplied in the dark to minimize sprouting and blackening. Incubation of explants at shortened illumination duration or in complete darkness has been used to reduce explant darkening in banana [32, 33]. Black coloration of in vitro cultured explants has been attributed to the accumulation of oxidized phenolics in cells resulting from the action of polyphenol oxidases on phenolic compounds exuded from stressed tissues [34]. Oxidized phenolic compounds are highly phytotoxic leading to cell death and release of phenolic compounds in growth medium [35-37]. Maintenance of plant tissue cultures in the dark decreases the activity of enzymes involved in the biosynthesis and oxidation of phenolic compounds [38].

\section{Regeneration of complete plantlets}

The regeneration of shoots from multiple buds was tested on several SEM supplemented with different BAP concentrations and containing activated charcoal. Shoots started sprouting on all the media as early as 10 days after culture of multiple buds (Fig. 1g). After 60 days of culture, most shoots achieved a length of at least $2 \mathrm{~cm}$ (Fig. 1h). The highest number (6.0) of shoots per cluster of multiple buds was obtained on SEM4 containing $2 \mathrm{mg} / \mathrm{l} \mathrm{BAP}$ media as compared to SEM2 with $0.5 \mathrm{mg} / \mathrm{l} \mathrm{BAP} \mathrm{(5.0)} \mathrm{and}$ SEM3 with $1.0 \mathrm{mg} / \mathrm{l} \mathrm{BAP} \mathrm{(5.3)} \mathrm{(Fig.} \mathrm{2c).} \mathrm{However} \mathrm{analy-}$ sis of variance indicated no significant difference among media treatments in the number of axillary shoots per explant. Our results agree with previous reports of successful shoot regeneration using media containing either BAP alone or a combination of high BAP with low auxin.
Genene and Mekbib [18] reported the development of 20-23 shoots per explant per subculture for different enset cultivars cultured on media having 4.5-6 mg/l BAP and $2 \mathrm{mg} / \mathrm{l}$ NAA. In this study SEM4 media with $2 \mathrm{mg} / \mathrm{l}$ BAP (hereafter referred to as SEM) was identified as the most ideal for shoot regeneration and elongation. The SEM medium is used routinely for shoot regeneration and plantlet maintenance (Fig. 1i).

Shoots were tested on different media for their ability to grow and initiate roots. Root development occurred 3-5 days after culture of shoots on all media. Root length varied from 0.03 to $0.97 \mathrm{~cm}$ across the tested media. There was no significant difference $(p>0.05)$ between RIM1 and RIM2 in root length. However, RIM1 treatment rendered significantly higher values $(p<0.05)$ than RIM3 and RIM4 in root length (Fig. 3a). This indicated that RIM1 was the most effective media for root induction and growth. Although roots can be induced on enset shoots using hormone-free media [19], the rooting frequency can be increased by the inclusion of between 1 and $2 \mathrm{mg} / \mathrm{l}$ IBA $[19,21]$. In this study, roots were induced as early as 3 days after culture of shoots on rooting medium. A maximum of 12 roots per shoot were obtained on RIM2 media with $1 \mathrm{mg} / \mathrm{l} \mathrm{IBA}$ and $0.1 \mathrm{mg} / \mathrm{l} \mathrm{BAP}$ (Fig. 3b). Previous studies have reported the induction of a fewer number of roots within a longer culture duration. Genene and Mekbib [18] reported the production of an average of 3.55 roots per explant after 12-14 days post culture of explants on MS media with $1 \mathrm{mg} / \mathrm{l} \mathrm{IBA}$. This differences in root induction response can be explained by the fact that root development is 

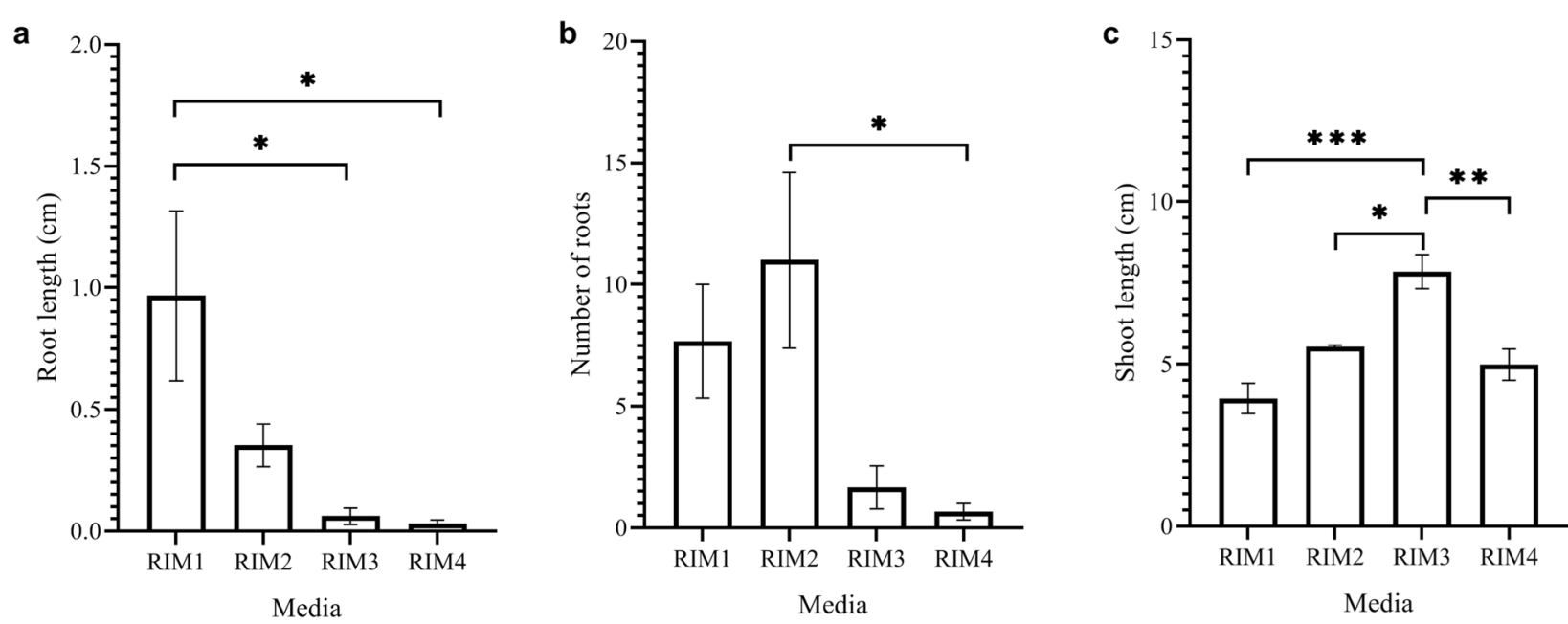

Fig. 3 Effect of different media on root and shoot development from multiple buds. a Effect of different media on root length, $\mathbf{b}$ effect of different media on number of roots, $\mathbf{c}$ effect of different media on shoot length. The bars represent mean and standard error for values on root length, number of roots or shoot length. Asterisk $\left(^{*}\right)$ indicate significant difference between means at $p<0.05$

dependent on several factors including media type and plant genotype. While root development decreased with increasing concentration of BAP in the culture media (Fig. 3a-b), shoot development increased with increasing BAP concentration (Fig. 3c). The longest shoots were obtained on RIM3 media (Fig. 3c). RIM3 treatment rendered significantly higher values than RIM1 $(p=0.0009)$, RIM2 $(p=0.0211)$ and RIM4 $(p=0.0065)$ in shoot length response (Fig. 3c).

Enset plantlets were transferred to sterile soil containing manure and acclimatized in a humid chamber in the glasshouse for 4 weeks (Fig. 1j). The potting mixture normally used is loamy soil and some other soft and waterretaining material (such as peat moss, vermiculite or red ash) mixed in a ratio of 1:1. Almost all the plants acclimatized in the glasshouse conditions, which is higher than the previous report of about $80 \%$ survival rate [19]. Successful acclimatization of plantlets largely depends on the sterility of the potting materials [20]. Acclimatized plantlets were transferred to bigger pots and grown under glasshouse conditions (Fig. 1k).

Organized cultures, especially the shoot tips, maintain strict genotypic and phenotypic stability under tissue culture conditions [25]. However, for enset, shoot tip culture resulted in high incidences (27\%) of somaclonal variation (off-types). About 4-15\% of the potted plants in the glasshouse showed wrinkled leaves, dwarfism or/and narrow leaves. Within genus Musa, shoot-tip cultures produced off-types at different rates ranging from 6 to $38 \%$ for Cavendish cultivars (Musa spp. AAA group) and $74 \%$ in plantain (Musa spp. AAB group) [39]. Evidently, the rate of somaclonal variation development is strongly influenced by genetic stability of each genotype, and its frequency is intensified by culture-induced factors. Tissue culture factors such as the number of subcultures [40] or the proliferation rates $[39,41]$ in vitro can strongly influence the incidence of somaclonal variation in the genus Musa. To reduce the incidence of somaclonal variation in enset cultivar Bedadeti, shoot tip explants for bud induction were routinely obtained from screen-house-grown plants rather than from plantlets maintained in vitro. Additionally, induced multiple buds were allowed to proliferate for a maximum of two subcultures of 14-21 days each.

\section{Sensitivity of multiple buds to kanamycin}

An effective selection strategy is very important to develop an efficient genetic transformation procedure. This can be achieved by the use of a selective agent which prevents non-transformed tissues from regenerating, while permitting the development of transformed cells into shoots without any lethality of the explant tissues [42]. The type of selectable marker genes and the selection pressure are very important factors for successful transformation. In this study, the $n p t I I$ gene, which confers the resistance to kanamycin, was used based on its application on other Musa species including banana $[8,23]$ and plantain [43]. To determine the selection pressure suitable for enset, multiple bud explants were cultured on media supplemented with different concentrations of kanamycin $(0,50,100,150,200 \mathrm{mg} / \mathrm{l})$. Multiple bud explants started to display kanamycin stress symptoms on selective shoot induction media within 4 weeks of culture. Within 8 weeks of culture, explants cultured on 0 or $50 \mathrm{mg} / \mathrm{l}$ kanamycin grew healthily and 

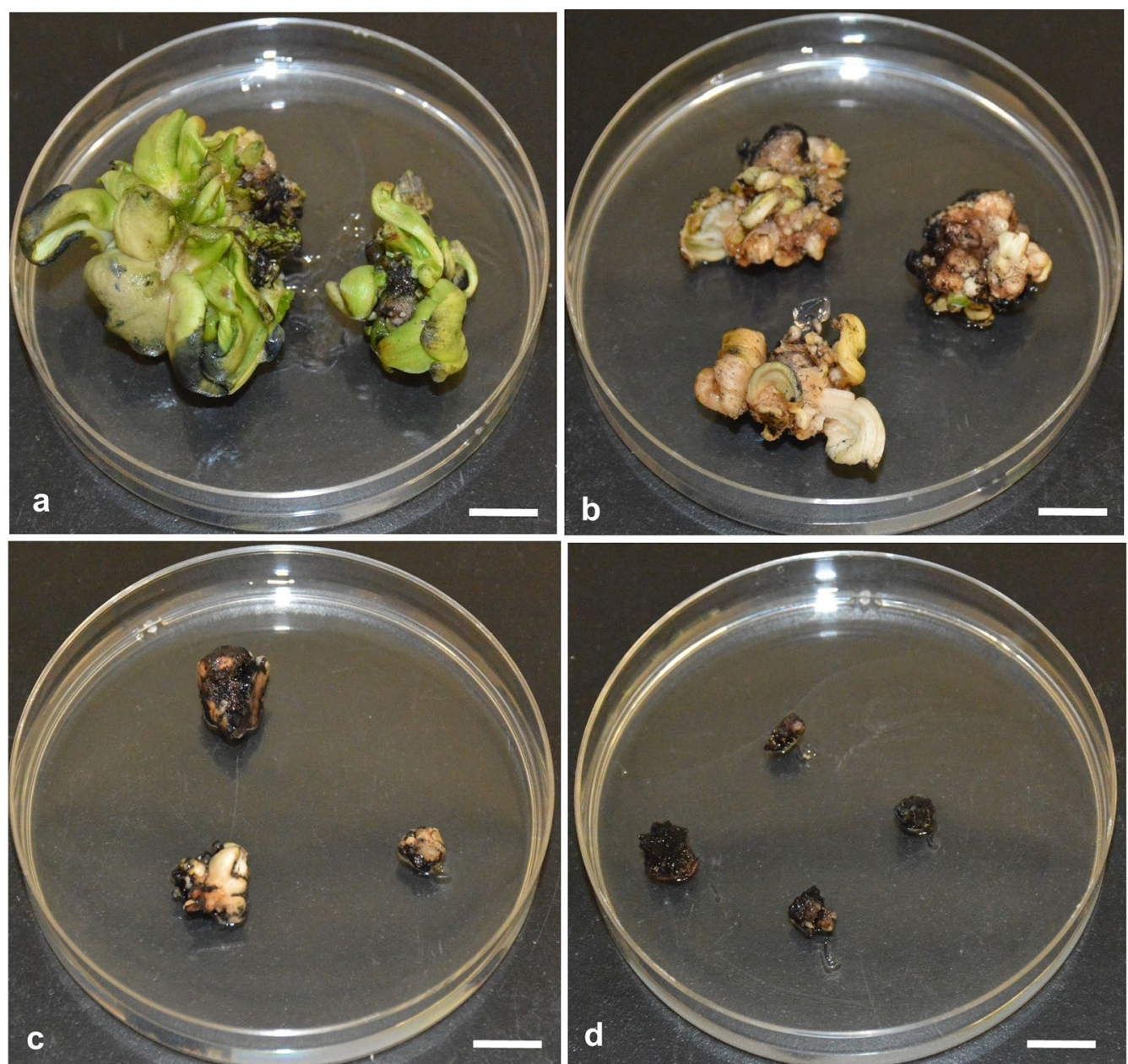

Fig. 4 Effect of different concentration of kanamycin on shoot regeneration from multiple buds of enset cv. Bedadeti cultured on selective regeneration medium supplemented with kanamycin. a 50 mg/l, b 100 mg/l, c 150 mg/l, d 200 mg/l. Pictures were taken 60 days post culture of multiple buds on selective medium using a digital camera (Nikon camera Model D7100, Nikon Corporation, Tokyo, Japan). Scale bar $=1 \mathrm{~cm}$

induced buds, which sprouted into green shoots (Fig. 4a). After 8 weeks on media with 100 or $150 \mathrm{mg} / \mathrm{l}$ kanamycin, explants developed bleached buds (Fig. 4b, c). There was no bud or shoot development on media having $200 \mathrm{mg} / \mathrm{l}$ kanamycin (Fig. 4d). Therefore, $150 \mathrm{mg} / \mathrm{l}$ of kanamycin was chosen as the minimum inhibitory concentration for selection of transformed enset tissues and shoots.

\section{Optimization of enset transformation using multiple buds as explants}

To develop a rapid protocol for generating transgenic enset plants using $A$. tumefaciens, the associated parameters were individually optimized using the established regeneration protocol described earlier. The parameters studied included the micro-wounding of explants by sonication prior to cocultivation, Agrobacterium strain, co-cultivation medium and resting duration for the recovery of Agro-infected tissues prior to the application of antibiotic selection.

\section{Effect of micro-wounding of explants on transformation}

The effect of micro-wounding of explants, through sonicating them for various durations, on transformation frequency was investigated. Multiple buds were sonicated for different times $(0-100 \mathrm{~s})$ and evaluated for transformation frequency following Agrobacterium mediated-transformation. Our results indicated that sonicated explants had higher transient expression of $g f p$ gene in comparison to non-sonicated tissues (Fig. 5a). These results are in accordance with previous results that indicate that sonication of tissues enhances transformation [27]. Sonication-assisted Agrobacterium-mediated transformation (SAAT) causes increased secretion of phenolic compounds from the micro-wounded surface and sub-surface layers of targeted tissue. Increased production of phenolic compounds attracts more Agrobacterium cells to the site of wounding, leading to an enhancement 
a

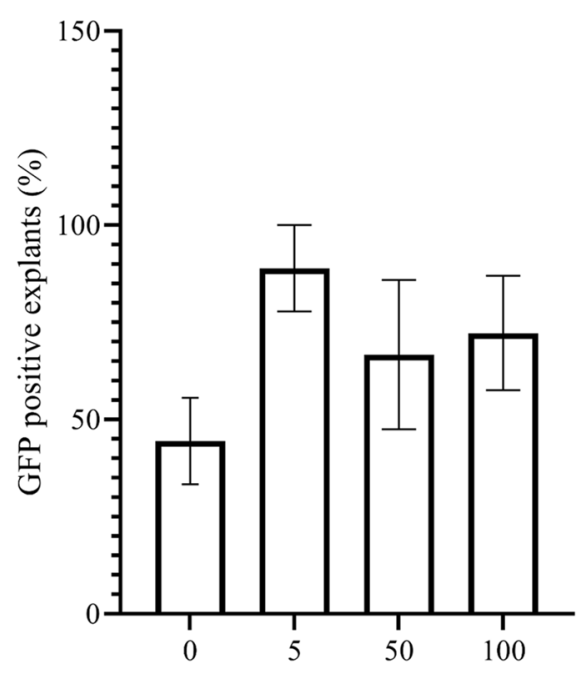

Sonication duration (seconds)

C

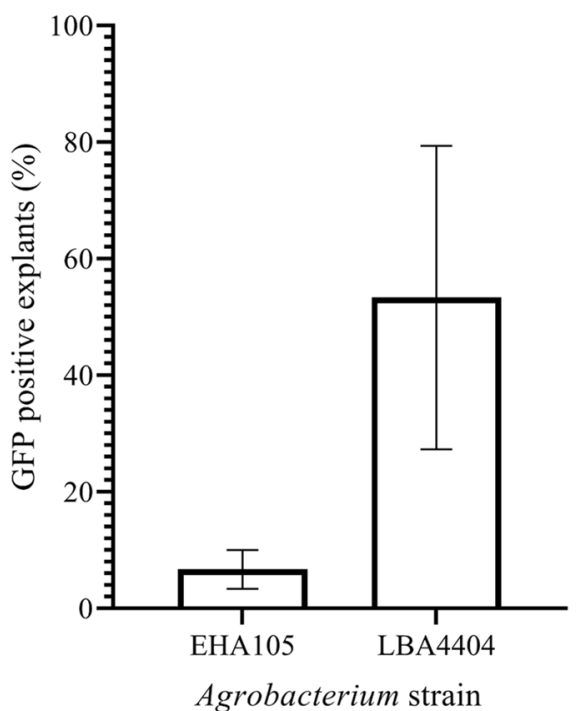

b

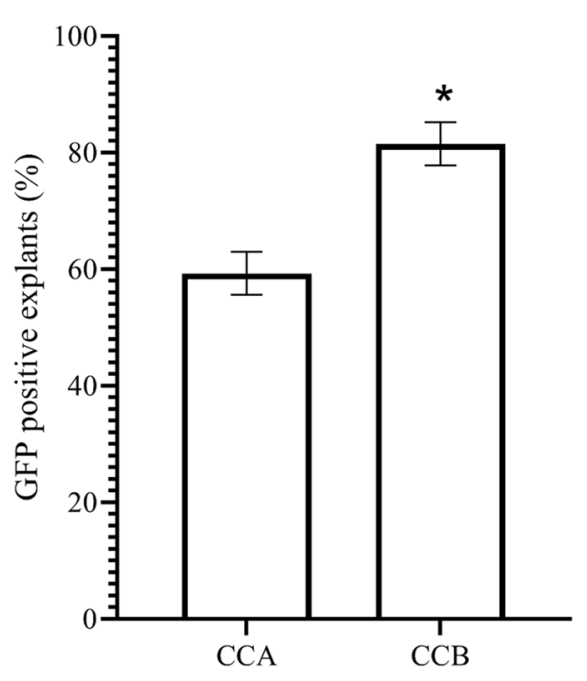

Cocultivation media type

d

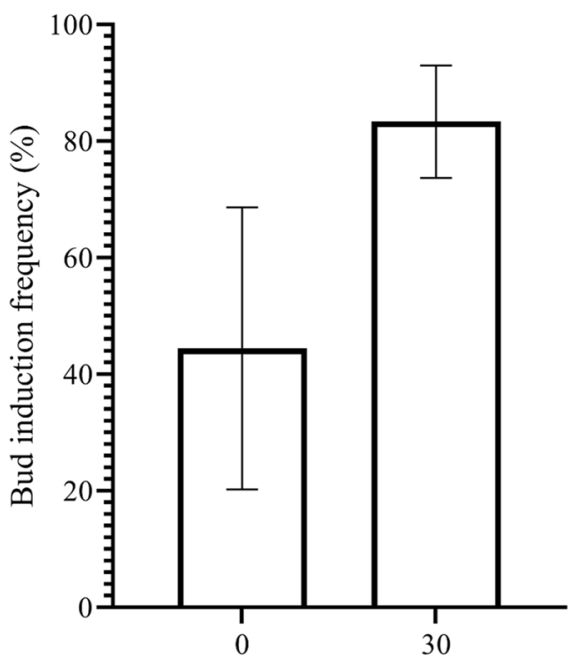

Resting duration (days)

Fig. 5 Optimization of different parameters for establishing transformation of enset using multiple buds. a Effect of sonication duration on transient expression of gfp reporter gene as percentage of multiple bud explants showing green fluorescence, $\mathbf{b}$ effect of types of cocultivation media on transient expression of gfp gene as percentage of multiple bud explants showing green fluorescence, $\mathbf{c}$ effect of Agrobacterium strains on transient expression of gfp gene as percentage of multiple bud explants showing green fluorescence, $\mathbf{d}$ effect of resting duration of Agro-infected multiple bud explants surviving on media with $150 \mathrm{mg} / \mathrm{l}$ kanamycin. The bars show the mean and standard error for values of expression of $\mathrm{gfp}$ gene as percentage of multiple bud explants showing green fluorescence and explant survival on selection media

in transformation efficiency [27]. Further, wounding of multiple buds has contributed to the generation of homogenously transformed plants [23, 24]. Our study showed that enset transformation was enhanced when explants were sonicated for $5 \mathrm{~s}$ resulting in a higher expression of $g f p$ gene in comparison to other treatments (Fig. 5a). In addition, none of the treatments affected the regeneration efficiency of explants. For all subsequent transformation experiments, all explants were sonicated for $5 \mathrm{~s}$ prior to co-cultivation.

\section{Effect of co-cultivation medium on transformation}

The effect of different co-cultivation media (CCA medium without glucose and CCB medium with glucose) on transformation frequency was investigated. Co-cultivation of explants with Agrobacterium in the 
glucose-containing CCB medium resulted in a significantly higher $(p=0.0132)$ transformation efficiency than cultivation on CCA medium (Fig. 5b). However, the CCB media also promoted heavy overgrowth of Agrobacterium on explants. The explants cultured on the CCB medium could not be recovered by washing off excess Agrobacterium with RM media containing $500 \mathrm{mg} / \mathrm{l}$ cefotaxime and explants became highly blackened shortly after culturing on resting media. The enhancement of transformation frequency by $\mathrm{CCB}$ medium can be attributed to the presence of glucose. Glucose and other aldose monosaccharides activate the chromosomally encoded periplasmic protein (ChvE) which mediates a sugar-induced increase in $\mathrm{Vir}$ gene expression as well as Agrobacterium chemotaxis. In addition, glucose works synergistically with acetosyringone to enhance the transformation frequency [44]. Similar to transformation procedures for other monocots, acetosyringone $(200 \mu \mathrm{M})$ was added to the co-culture media to induce $A$. tumefaciens to infect plants cells. Acetosyringone works by activating the $V i r$ gene found on the A. tumefaciens helper plasmid. Our results showed less overgrowth of Agrobacterium when explants were co-cultivated in CCA medium. Therefore, CCA medium was used in all subsequent experiments.

\section{Effect of Agrobacterium strain on transformation}

The effect of Agrobacterium strain on transformation frequency was investigated. The transformation frequencies of enset multiple bud infection with the Agropine strain EHA105 or the Octopine strain LBA4404 of A. tumefaciens were compared. Results indicated that enset is sensitive to both EHA105 and LBA4404, however, LBA4404 produced higher transformation frequencies than EHA105 (Fig. 5c). One of the challenges associated with $A$. tumefaciens-mediated transformation is the variability in competency of different Agrobacterium strains to plant infection. This implies that susceptibility to Agrobacterium is speciesspecific, making it essential to identify the best strain for the crop under study. EHA105 has been used as the strain of choice in the transformation of different Musa species including banana $[8,45,46]$ and plantain [47]. However, efficient transformation of enset was achieved using LBA4404 in our study. Consequently, LBA4404 was used in subsequent stable transformation experiments.

\section{Effect of resting phase on transformation}

The effect of resting phase without a selective agent on the regeneration of infected explants was evaluated. The regeneration response of Agro-infected explants to different resting durations ( 0 or 30 days) was compared. The transformation method involving a resting phase of 30 days resulted in sprouting of $84 \%$ of Agro-infected explants, whereas the method devoid of resting phase showed a regeneration of only $44 \%$ of explants (Fig. $5 \mathrm{~d}$ ). Several transformation protocols of banana and plantain recommend the culture of Agro-infected explants on non-selective media after co-cultivation for better transformation efficiency [48]. The resting phase allows explants to recover from the shock and damage associated with Agro-infection thereby increasing their chances of surviving on selective medium. In addition, the resting phase gives the opportunity to small and slow-responding cells to grow, thereby improving the tolerance of putative transgenic tissues to selective agent. This may result in better differentiation and sprouting in later stages of regeneration. Our results showed enhanced transformation of enset when Agro-infected explants were rested before selection. Consequently, a resting phase was included in all the subsequent transformation experiments.

\section{Stable transformation and chimera dissociation in transgenic plants}

Stable transformation of enset was achieved using the best responses for the parameters tested. This involved infection of micro-wounded explants with Agrobacterium strain LBA4404 using co-cultivation medium CCA for 3 days. Agro-infected explants were cultured on medium without selection for 30 days before regeneration of explants on SRM containing $150 \mathrm{mg} / \mathrm{l}$ kanamycin. Shoot induction occurred within 6-8 weeks with the explants producing distinct buds on SRM (Fig. 6a; Additional file 2: Fig. S2a). After 8-9 weeks of selection, the buds sprouted into shoots (Fig. 6b). About $11.9 \%$ of the Agro-infected explants showed regeneration on SRM, however, only 4.33\% Agro-infected explants developed putative transgenic shoots. A total of 12 putative transformed shoots were obtained, which were validated by PCR analysis using primers specific to nptII gene. Eight out of 12 transgenic events were PCR positive, confirming the presence of $n p t \mathrm{II}$ gene. UV illumination from a fluorescence stereomicroscope also detected stable expression of $g f p$ gene in buds and regenerated tissues of these transformants (Fig. 6d-f). To ensure that all plantlets were uniformly transformed, the PCR positive transgenic events were subjected to chimera dissociation.

Very high incidences of chimeric plantlets (over 60\%) have been reported for meristem transformation in different monocot species including banana [23], maize [49], rice [50] and bluegrass [51]. One way of overcoming this technological barrier for Musa species may be to perform a second round of selection for all putative transformants 

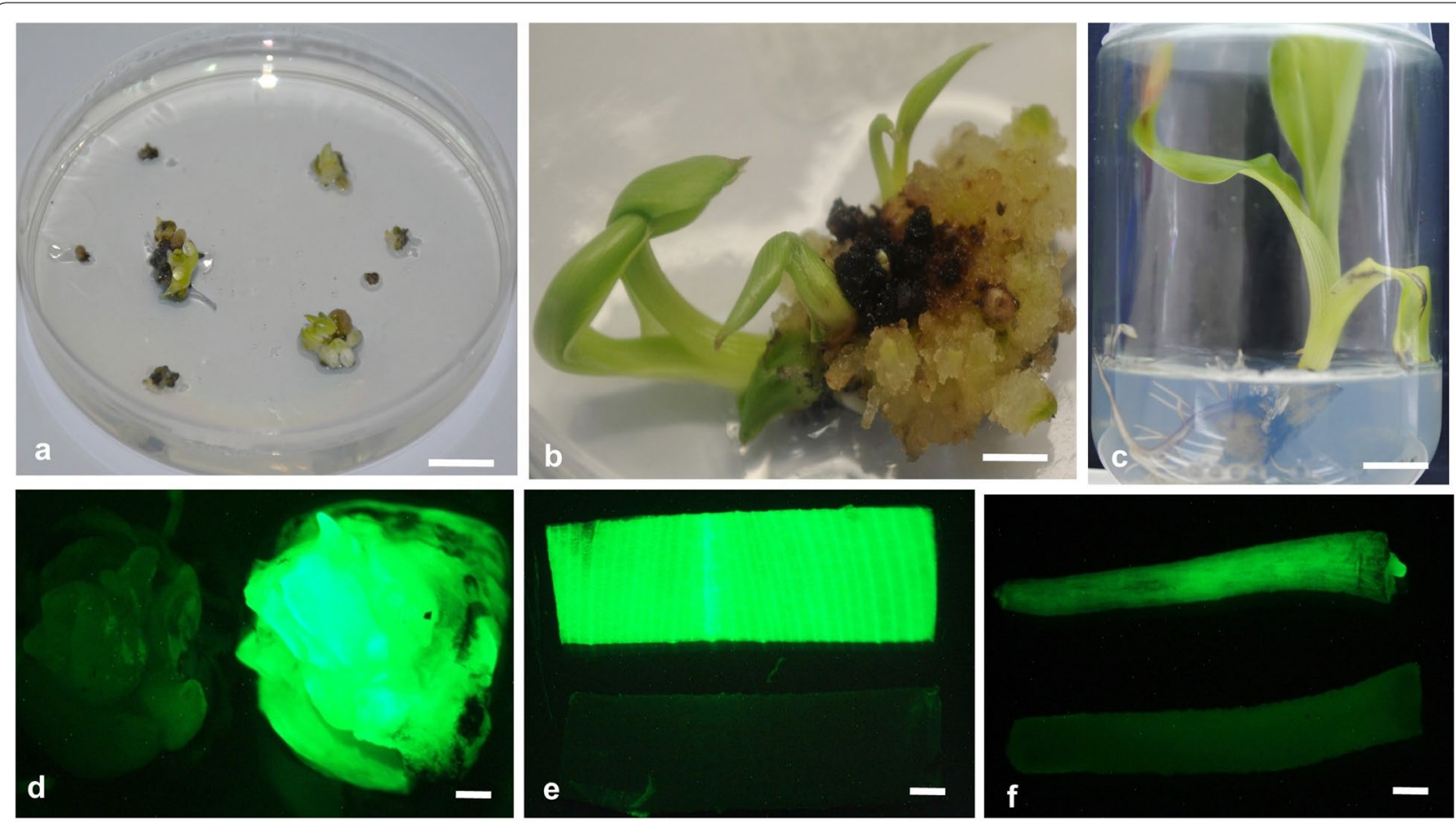

g

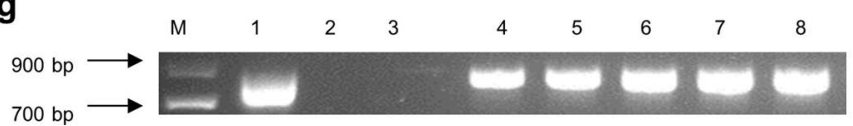

i

h
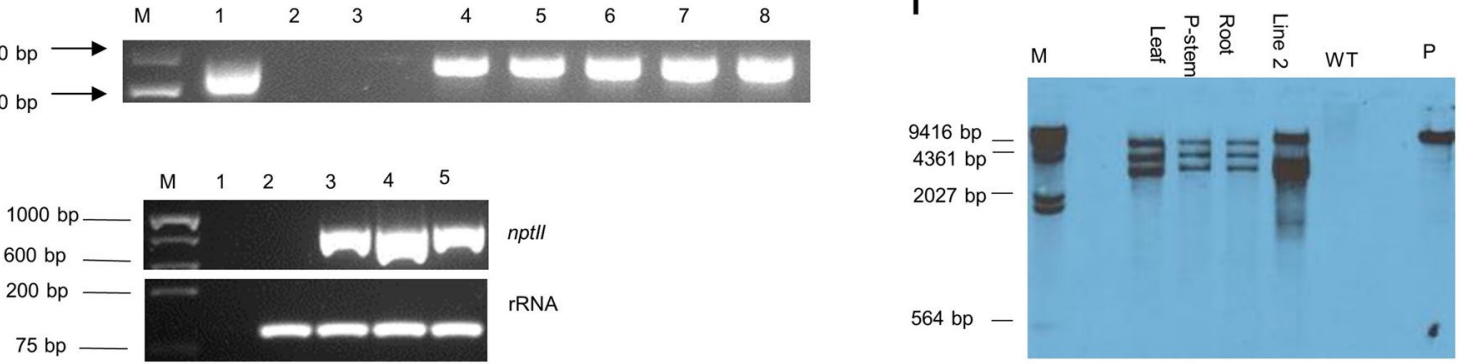

Fig. 6 Generation and characterization of transgenic events of enset using gfp as reporter gene. a Agro-infected multiple bud explants cultured on selective medium 30 days after transformation, $\mathbf{b}$ regeneration of shoots from Agro-infected explants on selective medium, $\mathbf{c}$ fully developed transgenic plantlet after 5 cycles of selection for chimera dissociation on medium having $150 \mathrm{mg} / \mathrm{l}$ kanamycin, $\mathbf{d}$ distinct bud showing expression of gfp gene post 60 days after co-cultivation. e, $\mathbf{f}$ Expression of gfp gene in leaf and root tissues excised from transgenic plantlet, $\mathbf{g}$ PCR amplification of the nptll gene in different chimera diluted transgenic events. Lane M, 1 Kb plus DNA ladder; Lane 1, pCAMBIA2300-GFP; Lane 2, non-template control; Lane 3, non-transformed control; Lane 4-8, chimera diluted transgenic events 1-5, h RT-PCR analysis of different tissues of the uniformly transformed plantlets using primers specific to nptll gene. Lane M, 100 bp ladder; Lane 1, non-template control; Lane 2, non-transformed control; Lane 3, Leaf of transgenic plantlet; Lane 4, pseudostem of transgenic plantlet; Lane 5, root of transgenic plantlet. i Southern hybridization analysis of transformed plantlets. Genomic DNA was digested with Hindlll and probed with a DIG-labelled fragment (780 bp) of $n p t l l$ gene. Lane M, DIG-labelled Lambda HindIII ladder; Lane WT, non-transformed control DNA; Lane P, pCAMBIA2300-GFP, Scale bar $=1 \mathrm{~cm}$ in a-c and $0.5 \mathrm{~cm}$ in d-f

$[8,23]$. Therefore, in this study, all regenerated transgenic events underwent chimera dissociation treatment consisting of the culture of shoot tip explants on CDM1 for 7 days followed by the culture on CDM2 for 14 days. Several studies reported that two cycles of explant regeneration on high kanamycin $(100-150 \mathrm{mg} / \mathrm{l})$ was sufficient for successful chimera dissociation [8, 23, 26]. However, development of a robust root system from explants on selective medium may be a more reliable indicator of uniform transformation [22, 23]. Therefore, in this study, the emergence of roots on explants exposed to $150 \mathrm{mg} / \mathrm{l}$ kanamycin was used as an indicator of successful dissociation of chimeras. Our results indicated that the majority of the explants survived (with some rooting) on cycle 1 of chimera dissociation. However, most (over 60\%) of the explants did not grow on cycle 2 and 3, but instead turned brown and died or produced bleached shoots (Additional file 2: Fig. S2b). The surviving green shoots 
Excise shoot tips $(\sim 1 \mathrm{~cm})$ and induce buds

(BIM)

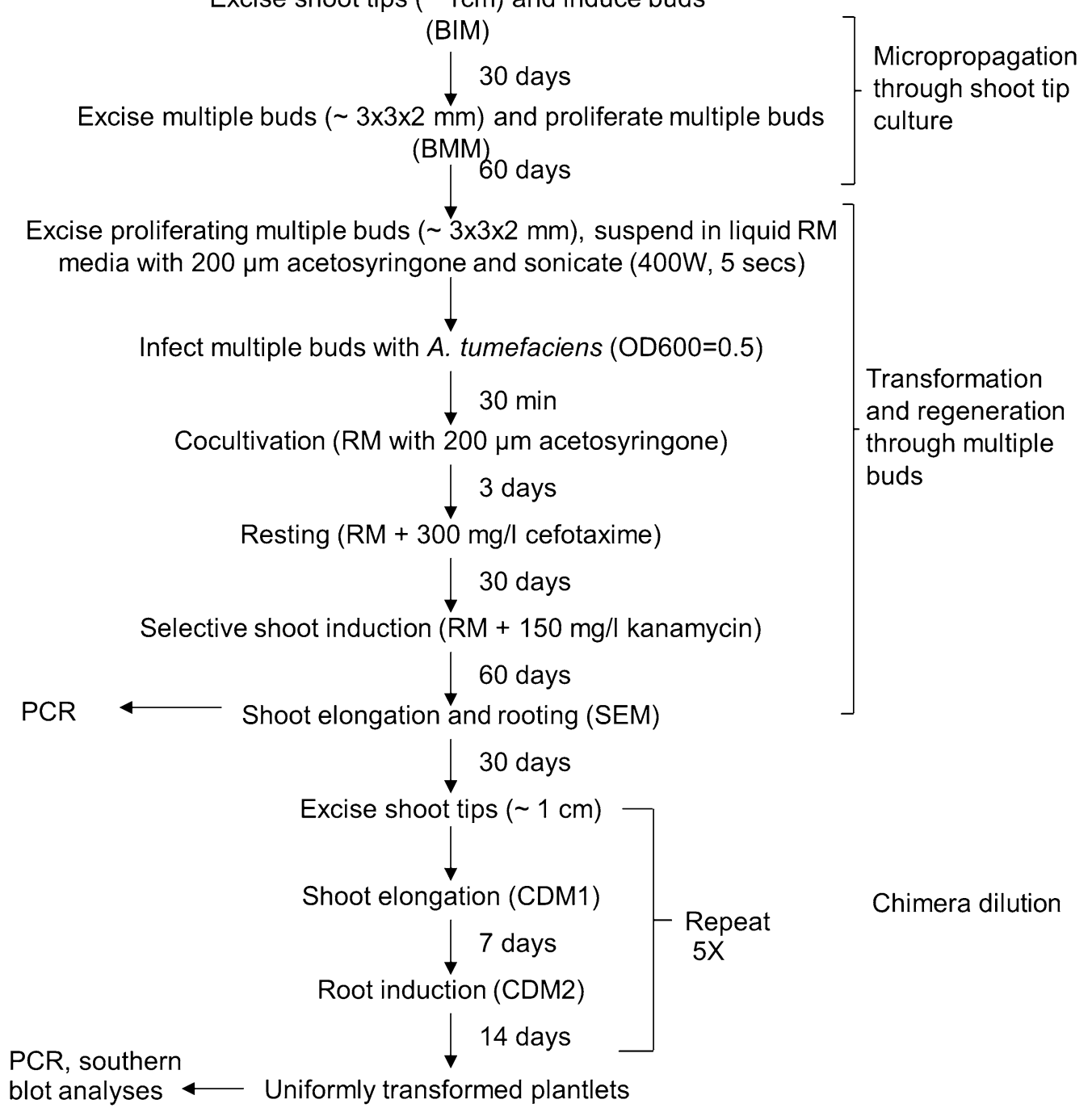

Fig. 7 Schematic flow diagram showing steps in genetic transformation of enset using proliferating multiple buds as explants. BIM, bud induction medium; BMM, bud multiplication medium; RM, regeneration medium; SEM, shoot elongation medium; CDM1, chimera dilution medium 1; CDM2, chimera dilution medium 2

were transferred to 4 th cycle of selection (Additional file 2: Fig. S2c). Roots were initiated when the surviving shoots were transferred to the 4th cycle of selection. A final (5th) cycle of selection was therefore necessary to achieve full plantlet development. After 5 cycles of selection, the fully developed shoots were deep green in color and well rooted (Fig. 6c). Five out of the 8 transgenic events survived chimera dilution. These surviving events were confirmed uniformly transformed through PCR, RT-PCR and Southern blot hybridization. Surviving plantlets were maintained on SEM media (Additional file 2: Fig. S2d).

\section{Molecular analyses of transgenic events}

The transgenic events that survived extensive selection for chimera dilution were characterized by PCR using $n p t \mathrm{II}$ gene-specific primers to confirm the presence of transgene. The expected fragment size of $780 \mathrm{bp}$ was obtained in the transgenic plants (Fig. 6g, lanes 4-8) and positive control pCAMBIA2300-GFP plasmid DNA (Fig. 6g, lane 1). No amplicons were observed either on the non-template control (Fig. 6g, lane 2) or in the DNA from the non-transformed plantlets (Fig. 6g, lane 3). 
Transgene expression was analyzed by RT-PCR using $n p t \mathrm{II}$ gene-specific primers and cDNA prepared from different tissues of the chimera dissociated transgenic plant. The results revealed the expression of the $n p t \mathrm{II}$ gene in all tissues of the transgenic plant but not in the untransformed control plant (Fig. 6h). A transformation efficiency of $1.25 \%$ was achieved on the basis of the number of Agro-infected explants compared with the number of uniformly transformed PCR positive plants.

To further confirm the integration of transgene, Southern blot analysis was performed on gDNA obtained from two chimera-diluted events using the fragment of $n p t \mathrm{II}$ gene as the probe. Figure 6i shows $n p t I I$ hybridizing signals of the expected sizes for the control pCAMBIA2300-GFP plasmid (11,634 bp) and two transgenic events. There was consistent nptII hybridizing signals in leaf, pseudostem and root samples of the transgenic line 1. The Southern hybridization results also indicate that the T-DNA integrated into three sites on the genome of the transgenic line 1 and 2 . However the integration pattern for the two lines was different. No hybridization signal was detected in the non-transformed control (Fig. 6i).

The molecular analysis revealed a consistent transgene integration and expression pattern across all tissues of the transgenic plant, implying stable and uniform transformation of enset. Using the optimized protocol, putative transgenic enset plants can be generated in 4 months. A further 4 months is required for chimera dissociation to obtain uniformly transformed plantlets (Fig. 7).

\section{Conclusion}

This study reports a protocol for Agrobacterium-mediated transformation and regeneration of E. ventricosum. To our knowledge, this is the first report on stable transformation and regeneration of transgenic enset plants. The system, which is based on regeneration through multiple buds, is simple and delivers transgenic plants at an efficiency of $1.25 \%$. This protocol has been tested on Bedadeti and other cultivars in the laboratory. The study offers a method for genetic improvement of E. ventricosum cultivars and other Ensete species. Work is in progress to develop bacterial wilt-resistant $E$. ventricosum using the transformation protocol developed in this study.

\section{Supplementary information}

Supplementary information accompanies this paper at https://doi. org/10.1186/s13007-019-0512-y.
Additional file 1: Fig. S1. Schematic representation of the T-DNA region of binary plasmid pCAMBIA2300-GFP. Primer binding regions for amplification of nptll gene are indicated.

Additional file 2: Fig. S2. Generation of uniformly transformed transgenic events of enset. (a) Agro-infected explants cultured on selective regeneration medium containing $150 \mathrm{mg} / \mathrm{l}$ kanamycin, (b) regeneration of shoot tips isolated from putative transgenic shoots at cycle 2 of chimera dilution on selective regeneration medium. Green shoots were further transferred to selective regeneration medium and bleached non-transgenic shoots were discarded, (c) putative transgenic shoots at Cycle 4 of chimera dilution on selective regeneration medium containing $150 \mathrm{mg} / \mathrm{l} \mathrm{kanamycin}$, (d) uniformly transformed plants maintained on SEM media with $2 \mathrm{mg} / \mathrm{l}$ BAP and $0.2 \%$ activated charcoal. Scale bar $=1.5 \mathrm{~cm}$.

\section{Acknowledgements}

Authors thank Rose H. Okech for her assistance with maintenance and multiplication of in vitro cultures of enset.

\section{Authors' contributions}

LT conceived the idea, contributed in designing experiments, analyzing results and writing the manuscript. JM designed and performed the experiments, analyzed the results and wrote the manuscript. JNT was involved in the transformation, RT-PCR and Southern blot analyses. IM was involved in development of the tissue culture protocols. All authors read and approved the final manuscript.

\section{Funding}

This work was supported by the Bill and Melinda Gates Foundation (OPP1079038).

\section{Availability of data and materials}

All data generated or analyzed during this study are available in this published article.

\section{Ethics approval and consent to participate}

Not applicable.

\section{Consent for publication}

All authors agreed to publish this manuscript.

Competing interests

The authors declare that they have no competing interests.

\section{Author details}

${ }^{1}$ International Institute of Tropical Agriculture (ITA), Nairobi, Kenya. ${ }^{2}$ Ethiopian Institute of Agricultural Research (EIAR), Addis Ababa, Ethiopia.

Received: 20 August 2019 Accepted: 28 October 2019

Published online: 08 November 2019

References

1. Central Statistical Agency (CSA). Report on area and production of major crops. Statistical Bulletin 532; Addis Ababa, Ethiopia. 2013. p. 10-4.

2. Borrell JS, Biswas MK, Goodwin M, Blomme G, Schwarzacher T, HeslopHarrison JS, Wendawek AM, Berhanu A, Kallow S, Janssens S, Molla EL. Enset in Ethiopia: a poorly characterized but resilient starch staple. Ann Bot. 2019;123(5):747-66.

3. Yemataw Z, Mohamed H, Diro M, Addis T, Blomme G. Enset (Ensete ventricosum) clone selection by farmers and their cultural practices in southern Ethiopia. Genet Resour Crop Evol. 2014;61 (6):1091-104.

4. Brandt SA, Spring A, Hiebsch C, MCCabe ST, Taboge E, Diro M, WeldeMichael G, Yentiso G, Shigeta M, Tesfaye S. The 'Tree Against Hunger'. Enset-based Agricultural Systems in Ethiopia. Washington DC: American Association for the Advancement of Science; 1997. p. 56. 
5. Tsegaye A, Westphal E. Ensete ventricosum (Welw.) Cheesman. Record from Protabase. Oyen, LPA, Lemmens, RHMJ PROTA (Plant Resources of Tropical Africa/Resources végétables de l'Afrique tropicale), Wageningen, The Netherlands. 2002.

6. Yirgou D, Bradbury JF. Bacterial wilt of enset (Ensete ventricosum) incited by Xanthomonas musacearum sp. Phytopathology. 1968;58:111-2.

7. Castellani E. Su un marciume dell'ensete. L'Agric Coloniale Firenze. 1939;33:297-300

8. Tripathi L, Tripathi JN, Tushemereirwe WK. Rapid and efficient production of transgenic East African Highland Banana (Musa spp.) using intercalary meristematic tissues. Afr J Biotechnol. 2008;7(10):1438-45.

9. Blomme G, Jacobsen K, Ocimati W, Beed F, Ntamwira J, Sivirihauma C, et al. Fine-tuning banana Xanthomonas wilt control options over the past decade in East and Central Africa. Eur J Plant Pathol. 2014;139:265-81.

10. Diro M, Van Staden J. In vitro regeneration of Ensete ventricosum from zygotic embryos of stored seeds. S Afr J Bot. 2003;69(3):364-9.

11. Bezuneh T. An overview on enset research and future technological needs for enhancing its production and utilization. In: Tsedeke A, Hiebisch C, Brandt SA, Seifu G, editors. Enset based sustainable agriculture in Ethiopia. Proceedings from the international workshop on enset held in Addis Ababa, 13-20 December 1993. p. 3-12.

12. Dale J, James A, Paul JY, Khanna H, Smith M, Peraza-Echeverria S, GarciaBastidas F, Kema G, Waterhouse P, Mengersen K, Harding R. Transgenic Cavendish bananas with resistance to Fusarium wilt tropical race 4 . Nat Commun. 2017;8:1-8.

13. Yip MK, Lee SW, Su KC, Lin YH, Chen TY, Feng TY. An easy and efficient protocol in the production of pflp transgenic banana against Fusarium wilt. Plant Biotechnol Rep. 2011;5:245-54

14. Tripathi L, Tripathi JN, Kiggundu A, Korie S, Shotkoski F, Tushemereirwe WK. Field trial of Xanthomonas wilt disease-resistant bananas in East Africa. Nat Biotechnol. 2014;32:868-70.

15. Tripathi L, Babirye A, Roderick H, Tripathi JN, Changa C, Urwin PE, Tushemereirwe WK, Coyne D, Atkinson HJ. Field resistance of transgenic plantain to nematodes has potential for future African food security. Sci Rep. 2015;5:8127.

16. Morpurgo R, Afza R, Novak FJ. Biotechnology and Enset achievements and prospective. In: Enset sustainable agriculture in Ethiopia proceedings 1996, Ethiopia, Addis Abeba. 1993. p. 256-72.

17. Tripathi J, Matheka J, Merga I, Gebre E, Tripathi L. Efficient regeneration system for rapid multiplication of clean planting material of Enseteventricosum (Welw.) Cheesman. Vitro Cell Dev Biol Plant. 2017;53(6):624-30.

18. Genene G, Mekbib F. In vitro regeneration of disease free enset [Ensete ventricosum (Welw) Cheesman] planting materials from bacterial wilt diseased plants using shoot tip culture. Afr J Biotechnol. 2016;15(40):2192-201.

19. Birmeta, G. Genetic Variability and biotechnological studies for the conservation and improvement of Ensete ventricosum. PhD dissertation. Sweden: Swedish University of Agricultural Sciences; 2004. p. 27-9.

20. Negash A, Puite K, Schaart J, Visser B, Krens F. In vitro regeneration and micro-propagation of enset from Southwestern Ethiopia. Plant Cell Tissue Organ Cult. 2000;62(2):153-8.

21. Afza R, Van Duren M, Morpurgo R. Regeneration of Ensete ventricosum through somatic embryogenesis and adventitious buds. Plant Cell Rep. 1996;15:445-8.

22. Chi-manzanero BH, Acereto-Escoffi POM, Castano E, Rodriquez-Zapata LC Optimal concentration of kanamycin as a selective agent for the transformation of Musa cv. "Grand Nain". Universidad Ciencia. 2010;26(1):115-9.

23. Subramanyam K, Subramanyam K, Sailaja KV, Srinivasulu M, Lakshmidevi K. Highly efficient Agrobacterium-mediated transformation of banana cv. Rasthali (AAB) via sonication and vacuum infiltration. Plant Cell Rep. 2011;30(3):425-36.

24. May GD, Afza R, Mason HS, Wiecko A, Novak FJ, Arntzen CJ. Generation of transgenic banana (Musa acuminata) plants via Agrobacterium-mediated transformation. Nat Biotechnol. 1995;13(5):486-92.

25. Lakshmanan V, Venkatarmareddy SR, Neelwarne B. Molecular analysis of genetic stability in long-term micropropagated shoots of banana using RAPD and ISSR markers. Electron J Biotechnol. 2007;10(1):1-11.

26. Faize M, Faize L, Burgos L. Using quantitative real-time PCR to detect chimeras in transgenic tobacco and apricot and to monitor their dissociation. BMC Biotechnol. 2010;2010:10.
27. Trick HN, Finer JJ. SAAT: sonication-assisted Agrobacterium-mediated transformation. Transgenic Res. 1997;6(5):329-36.

28. Hood EE, Helmer GL, Fraley RT, Chilton M. The hyper-virulence of Agrobacterium tumefaciens A281 is encoded in a region of pTiBo542 outside of T-DNA. J Bacteriol. 1986;68:1291-301.

29. Hoekema A, Hirsch PR, Hooykaas PJJ, Schilperoort RA. A binary vector strategy based on separation of vir- and T-region of the Agrobacterium tumefaciens Ti plasmid. Nature. 1983;303:179-80.

30. Chimsa MD. In vitro propagation of enset (Ensete ventricosum (Welw.) Cheesman). PhD dissertation. South Africa: University of KwaZulu-Natal; 2003. p. 44.

31. Negash A, Krens F, Schaart J, Visser B. In vitro conservation of enset under slow-growth conditions. Plant Cell Tissue Organ Cult. 2001;66:107-11.

32. Titov S, Bhowmik SK, Mandal A, Alam S, Uddin SN. Control of phenolic compound secretion and effect of growth regulators for organ formation from Musa spp. cv. Kanthali Floral bud explants. Am J Biochem Biotechnol. 2006;2(3):97-104.

33. IsraeliY, Lahav E, Reuveni O. In vitro culture of bananas. In: Gowen S, editor. Bananas and plantains. London: Chapman \& Hall Publishers; 1995. p. $147-78$.

34. Chuanjun X, Zhiwei R, Ling L, Biyu Z, Junmei H, Wen H, Ou H. The effects of polyphenol oxidase and cycloheximide on the early stage of browning in Phalaenopsis explants. Hortic Plant J. 2015;1(3):172-80.

35. Jones AMP, Saxena PK. Inhibition of phenylpropanoid biosynthesis in Artemisia annua L.: a novel approach to reduce oxidative browning in plant tissue culture. PLoS ONE. 2013;8(10):e76802.

36. Ko WH, Su CC, Chen Cl, Chao CP. Control of lethal browning of tissue culture plantlets of Cavendish banana CV. Formasana with ascorbic acid. Plant Cell Tissue Organ Cult. 2008;2008(96):137-41.

37. Martin KP, Zhang CL, Sltater A, Madassery J. Control of shoot necrosis and plant death during micro-propagation of banana and plantains (Musa spp). Plant Cell Tissue Organ Cult. 2007;88:51-9.

38. Ahmad I, Hussain T, Ashraf I, Nafees M, Maryam RM, labal M. Lethal effects of secondary metabolites on plant tissue culture. Am Eurasian J Agric Environ Sci. 2013;13(4):539-47.

39. Vuylsteke D, Swennen R, De Langhe E. Somaclonal variation in plantains (Musa spp., AAB group) derived from shoot-tip culture. Fruits. 1991:46(4):329-439.

40. Rodrigues PHV, Tulmann Neto A, Cassieri Neto P, Mendes BMJ. Influence of the number of subcultures on somaclonal variation in micropropagated Nanicão (Musa spp., AAA Group). Acta Hort. 1998;490(490):469-74.

41. Bairu MW, Fennell CW, Van Staden J. The effect of plant growth regulators on somaclonal variation in Cavendish banana (Musa AAA cv. 'Zelig'). Sci Hortic. 2006;108(4):347-51.

42. Song G, Walworth A, Hancock JF. Factors affecting Agrobacterium-mediated transformation of switch grass cultivars. Plant Cell Tissue Organ Cult. 2012;108:445-53.

43. Tripathi J, Muwonge A, Tripathi L. Highly efficient regeneration and transformation protocol for plantain cv. Gonja manjaya (Musa spp. AAB) using embryogenic cell suspension. Vitro Cell Dev Biol Plant. 2012;48:216-24.

44. Srinivasan R, Gothandam KM. Synergistic action of D-glucose and acetosyringone on Agrobacterium strains for efficient Dunaliella transformation. PLOS ONE. 2016;11(6):e0158322.

45. Ghosh A, Ganapathi TR, Nath P, Bapat VA. Establishment of embryogenic cell suspension cultures and Agrobacterium-mediated transformation in an important Cavendish banana cv. Robusta (AAA). Plant Cell Tissue Organ Cult. 2009;97(2):131-9.

46. Huang X, Huang XL, Xiao W, Zhao JT, Dai XM, Chen YF, Li XJ. Highly efficient Agrobacterium-mediated transformation of embryogenic cell suspensions of Musa acuminata cv. Mas (AA) via a liquid co-cultivation system. Plant Cell Rep. 2007;26:1755-62.

47. Tripathi L, Tripathi JN, Hughes Jd'A. Agrobacterium-mediated transformation of plantain cultivar Agbagba (Musa spp.). Afr J Biotechnol. 2005;4:1378-83.

48. Sagi L, Panis B, Remy S, Schoofs H, De Smet K, Swennen R, Cammus B. Genetic transformation of banana (Musa spp.) via particle bombardment. Biotechnology. 1995;13:481-5.

49. Sairam RV, Parani M, Franklin G, Lifeng Z, Smith B, MacDougall J, Wilber C, Sheikh H, Kashikar N, Meeker K, Al-Abed D, Berry K, Vierling R, Goldman SL. Shoot meristem: an ideal explant for Zea mays L. transformation. Genome. 2003:46:323-9. 
50. Yookongkaew N, Srivatanakul M, Narangajavana J. Development of genotype-independent regeneration system for transformation of rice (Oryza sativa ssp. indica). J Plant Res. 2007;120(2):237-45.

51. Zhang K, Wang J, Hu X, Yang A, Zhang J. Agrobacterium-mediated transformation of shoot apices of Kentucky bluegrass (Poa pratensis L.) and production of transgenic plants carrying a betA gene. Plant Cell Tissue Organ Cult. 2010;102(2):135-43.

\section{Publisher's Note}

Springer Nature remains neutral with regard to jurisdictional claims in published maps and institutional affiliations.
Ready to submit your research? Choose BMC and benefit from:

- fast, convenient online submission

- thorough peer review by experienced researchers in your field

- rapid publication on acceptance

- support for research data, including large and complex data types

- gold Open Access which fosters wider collaboration and increased citations

- maximum visibility for your research: over $100 \mathrm{M}$ website views per year

At BMC, research is always in progress.

Learn more biomedcentral.com/submissions 